Rhode Island College

Digital Commons @ RIC

$11-25-2020$

\title{
A Review of Phenylephrine Versus Norepinephrine for the Treatmemnt of Maternal Hypotension During Spinal Anesthesia for Cesarean Delivery
}

Megan S. Sullivan

Follow this and additional works at: https://digitalcommons.ric.edu/etd

Part of the Nursing Commons

\section{Recommended Citation}

Sullivan, Megan S., "A Review of Phenylephrine Versus Norepinephrine for the Treatmemnt of Maternal Hypotension During Spinal Anesthesia for Cesarean Delivery" (2020). Master's Theses, Dissertations, Graduate Research and Major Papers Overview. 372.

https://digitalcommons.ric.edu/etd/372

This Major Paper is brought to you for free and open access by the Master's Theses, Dissertations, Graduate Research and Major Papers at Digital Commons @ RIC. It has been accepted for inclusion in Master's Theses, Dissertations, Graduate Research and Major Papers Overview by an authorized administrator of Digital Commons @ RIC. For more information, please contact digitalcommons@ric.edu. 


\section{A SYSTEMATIC REVIEW OF THE USE OF PHENLEPHRINE VERSUS NOREPINEPHRINE FOR THE TREATMENT OF MATERNAL HYPOTENSION \\ DURING SPINAL ANESTHESIA FOR CESAREAN DELIVERY}

by

Megan S. Sullivan

A Major Paper Submitted in Partial Fulfillment of the Requirements for the Degree of

Master of Science in Nursing

in

The School of Nursing

Rhode Island College

2019 


\begin{abstract}
Maternal hypotension is a common sequala of spinal anesthesia used during cesarean delivery. The current first line vasopressor used for treatment of maternal hypotension is phenylephrine. Administration of phenylephrine can cause a physiologic decrease in cardiac output that could contribute to adverse maternal or fetal outcomes. This systematic review was conducted to investigate the use of norepinephrine as an alternative vasopressor for the treatment of maternal hypotension. A database search was conducted using electronic sources including CINAHL, MEDLINE, Google Scholar and PubMed. Inclusion and exclusion criteria were used to narrow search results and the Critical Appraisal Skills Program checklist was applied to critically appraise selected randomized control trials. Five articles were selected to be included in this review. Key outcomes were compared between studies and included incidence of maternal hypotension, maternal cardiac output effects, incidence of bradycardia, incidence of intraoperative nausea and vomiting, and fetal effects on Apgar score and umbilical cord gases. Overall, norepinephrine was found to be of similar effectiveness to phenylephrine for the treatment of maternal hypotension. When compared to phenylephrine, norepinephrine was found to maintain maternal heart rate better, and had a lower incidence of maternal bradycardia. No difference was found between intervention groups in fetal Apgar scores and differences in fetal cord gases were varied between studies. This systematic review found that norepinephrine has similar efficacy to phenylephrine in ability to manage maternal hypotension with lower prevalence of bradycardia. Further research is needed into the overall safety of norepinephrine before routine clinical utilization.
\end{abstract}




\section{Acknowledgements}

To my husband, my family, and my friends. I could not stand strong if not for the foundation you have laid. Thank you. 


\section{Table of Contents}

Background/Statement of the Problem .......................................................... 1

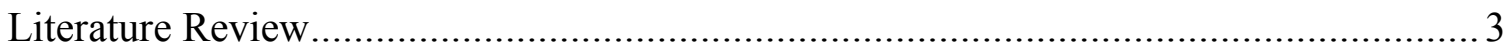

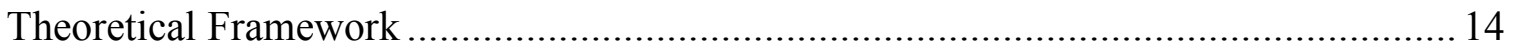

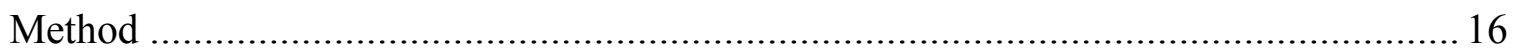

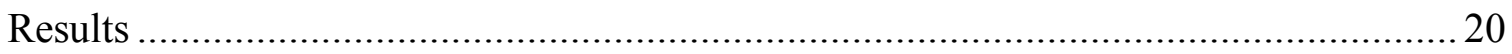

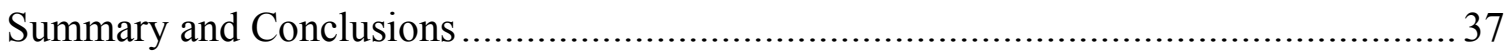

Recommendations and Implications for Advanced Nursing Practice ...........................4 40

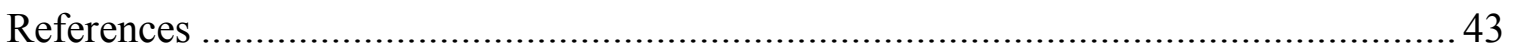

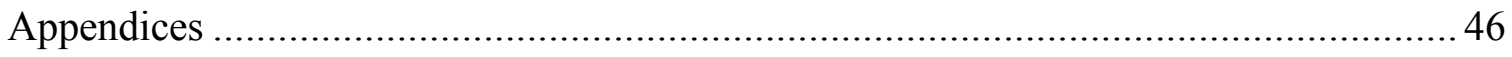


A Systematic Review of the Prophylactic Use of Phenylephrine Versus Norepinephrine for The Treatment of Maternal Hypotension During Spinal Anesthesia for Cesarean Delivery

\section{Background/Statement of the Problem}

Maternal hypotension, a common side effect of spinal anesthesia during cesarean delivery, is a highly studied area due to its potential impact on both the mother and the fetus. Rates of maternal hypotension as a consequence of spinal anesthesia performed during elective cesarean sections are $70-80 \%$ without prophylactic pharmacological management (Mercier, Augè, Hoffmann, Fisher \& Le Gouez, 2013). Hypotension during cesarean delivery can be potentially dangerous for both mother and fetus. A common maternal side effect from untreated hypotension is nausea and vomiting, but side effects may progress to cardiovascular collapse, loss of consciousness, pulmonary aspiration and cardiac arrest. Maternal hypotension can also cause fetal complications such as uteroplacental hypoperfusion and subsequent hypoxia, acidosis and neurological injury (Chooi et al., 2017; Nagelhout, Elisha \& Plaus, 2013).

Currently phenylephrine is the established first-line vasopressor for the treatment and prevention of maternal hypotension (Nagelhout et al., 2013). Phenylephrine is a potent direct-acting $\alpha_{1}$-adrenergic agonist; a pure vasoconstrictor. Due to its mechanism of action, a reflexive decrease in heart rate (HR) and a consequent decrease in cardiac output (CO) are common outcomes of phenylephrine administration (Ryu, Choi, Park, \& Kang, 2019). A 2010 study by Stewart et al. investigated the dose-dependent effects of phenylephrine administration during spinal anesthesia for cesarean sections and found marked decreases in maternal HR and $\mathrm{CO}$. While the study did not show any noticeable effects to the fetus, it was hypothesized that a decrease in $\mathrm{CO}$ may have a greater effect 
on a fetus during emergent situations where fetal $\mathrm{pH}$ may be more acidotic. In healthy women, the transient decreases in HR and $\mathrm{CO}$ that accompany phenylephrine administration appears to be accommodated without detrimental effect to the fetus. However, there is concern that the use of phenylephrine could negatively impact unhealthy mothers or fetuses with compromised health. For example, mothers with impaired cardiac function could theoretically have greater decreases in $\mathrm{HR}$ and $\mathrm{CO}$ that could impact fetal wellbeing. (Carvalho \& Dyer, 2015). The growing evidence that phenylephrine could cause detrimental effects to an at risk fetus has led to a renewed interest into alternative vasopressors for the use of treating maternal hypotension.

Norepinephrine, an $\alpha_{1}$-adrenergic agonist and a mild $\beta_{1}$-agonist, has been suggested as a potential alternative to phenylephrine. When used prophylactically, it has demonstrated the ability to maintain maternal blood pressure (BP) and increase both HR and cardiac contractility, while preserving CO during spinal anesthesia (Ryu, Choi, Park, \& Kang, 2019). While investigation into the use of norepinephrine versus phenylephrine is relatively new and ongoing, Ngan Kee, Lee, Ng, Tan, and Khaw's 2015 study into computer-controlled infusions of norepinephrine versus phenylephrine during spinal anesthesia for cesarean delivery found norepinephrine effective for prophylactically treating maternal hypotension.

The purpose of this paper is to conduct a systematic review to investigate the use of norepinephrine versus phenylephrine for the treatment of maternal hypotension during spinal anesthesia for cesarean delivery. 


\section{Literature Review}

\section{Anesthesia during Cesarean Deliveries}

Throughout history, there have been sporadic references to the use of cesarean section as a method to save both mother and infants. Purportedly the birth of Julius Caesar was via cesarean, and it is possible that this is the origin of the term "cesarean." It is also possible the term originates from the Latin word "caedare," which translates to cut, or from the term "caesones" which was historically the term applied to children born through postmortem procedures. In its earliest form, the procedure was typically done on a dead or dying mother to retrieve an infant and the rare reports of mother and baby surviving are dubious. Despite medical innovations, the surgery remained a serious procedure limited by patient's pain and lack of anesthesia. It was not until in the nineteenth century, when Queen Victoria utilized chloroform for the birth of two of her children that the use of anesthesia as an adjunct to childbirth became popular and practical (Sewell, 1993).

Today, cesarean deliveries are the most common major operating room procedure performed in the United States (HCUP Fast Stats, 2019). Modern medical advancements have increased the options available for anesthesia during obstetric procedures. Generally, there are two main types of anesthesia: general anesthesia or central neuraxial blocks. General anesthesia is the use of intravenous medications and/or inhaled anesthetics to induce a state of unconsciousness, analgesia, and amnesia (Nagelhout, et al., 2013). Central neuraxial blocks is the instillation of local anesthetic onto or near the spinal cord. Central neuraxial blocks for cesarean deliveries are sub divided between 
spinal and epidural anesthesia, with spinal being typically used for non-emergent cesarean deliveries if an epidural has not previously been placed for labor analgesia (Miller \& Pardo, 2011, p. 2344). Neuraxial blocks provide multiple benefits over general anesthesia among patients who require anesthetic management for obstetric procedures. Spinal and epidural anesthesia both have a lower risk for "nausea, vomiting, and urinary retention; a reduced total opioid requirement; and increased mental alertness compared with patients who have received general anesthesia alone" (Nagelhout et al., 2013, p. 1074). Other benefits include blunting of the stress response to pain or surgical stress, a lower incidence of post-surgical emboli, a decrease in perioperative blood loss, and improvements in respiratory function and cardiac stability (Nagelhout et al., 2013). Ultimately the decision of neuraxial anesthesia versus general anesthesia is based on multiple factors, including but not limited to: fetal condition, urgency of delivery, maternal health and co-existing health problems, surgical concerns and maternal preference (Miller \& Pardo, 2011,p. 2344).

\section{Spinal anesthesia for cesarean deliveries.}

The most common form of spinal anesthesia for cesarean delivery is a single-shot technique because of its reliability, ease of placement, and the quality of the sensory blockade achieved (Lim et al., 2018). The procedure for placing a single dose of spinal anesthesia is through the lumbar 3 and 4 vertebral disks. After the patient has been prepped and the site numbed a 22- to 25 -gauge needle is advanced between the spinous processes. Three ligaments will be passed through before puncturing the dura and seating the needle within the subarachnoid space where the medication of choice will be administered (Nagelhout et al., 2013, p. 1080). While this method is only one technique 
of administration, the results of spinal anesthesia are the same; administration of medication into the subarachnoid space.

Spinal anesthesia is commonly considered a superior option to general anesthesia because it is thought to be more practical and safer for mother and fetus. One way that fetal outcomes are assessed is through the Apgar assessment tool. It is a commonly used score based off five categories; heart rate, respiratory rate, newborn muscle tone, reflex irritability and skin coloring. Typically, the assessment is conducted at 1-minute and again at the 5-minute mark post-birth (Nagelhout et al., 2013). A 2012 study by Solangi, Khaskheli and Siddiqui compared general and spinal anesthesia on neonatal outcomes found that both Apgar score and fetal $\mathrm{pH}$ were more affected by general anesthesia. Unsatisfactory Apgar scores, as defined as a score less than 7, were observed in 25\% $(n=20)$ of the neonates whose mothers received general versus the $2.5 \%(n=2)$ within the spinal anesthesia group. The study also found that fetal $\mathrm{pH}$ levels were increasingly acidotic in the general anesthesia neonatal group and concluded that spinal anesthesia is favorable and preferred over general anesthesia (Solangi, Khaskheli \& Siddiqui, 2012).

\section{Maternal Hypotension.}

Spinal anesthesia is a safe and frequently used practice; however, it is not without predictable, undesirable side effects. Maternal hypotension, as defined as a twenty percent drop in blood pressure from baseline pressure and/or a blood pressure less than 90-100mmHg, is the most common side effect (Miller \& Pardo, 2011; Nagelhout et al., 2013). As previously mentioned, the incidence of hypotension as a side effect of spinal anesthesia during cesarean sections can be as high as $70-80 \%$ without prophylactic pharmacologic management (Mercier et al., 2013). Several factors can explain the high 
rates and the severity of maternal hypotension. Hypotension is primarily caused by hemodynamic changes due to spinal blockade and pharmacodynamic effects of local anesthetics, yet these hemodynamic changes can be compounded by other factors such as increased sensitivity to local anesthetics, the effects of pregnancy, and aortocaval compression of the enlarged uterus (Mercier et al., 2013).

Spinal anesthesia uses local anesthetics to produce a sympathetic nerve block to mitigate pain transmission. The blockade of the sympathetic nervous system can have varying effects upon the cardiovascular system. These changes include: arterial vasodilation, a reduction in systemic vascular resistance, and a decrease in venous return with a resulting decrease in blood pressure (Nagelhout et al., 2013, p. 1083). Extensive blocks may affect the innervation of cardioaccelerator fibers, found at T1-T4, which can lead to a marked decrease in venous return and bradycardia. A dense T4 blockade is required for cesarean section, so sympathectomy of the cardioaccelerators should be anticipated. Resulting unopposed parasympathetic outflow can also affect the compensatory reflexes to decreases in blood pressure such as baroreceptors, and volume receptors (Miller \& Pardo, 2011; Nagelhout et al., 2013).

Pharmacological effects of local anesthetics used in neuraxial blocks may also be enhanced by physiologic changes because of pregnancy. As soon as the first trimester, pregnant women become increasingly sensitive to local anesthetic pharmacological affects. A study by Butterworth, Walker, and Lysak in 1990 found that median nerve transmission was more susceptible to lidocaine block in pregnant women versus nonpregnant women. It was hypothesized that changes in cellular mechanism could increase susceptibility in pregnant women through changes to the $\mathrm{Na}+$ channel where 
local anesthetics produce affect (Butterworth, Walker \& Lysak, 1990). The increase sensitivity to local anesthetics may increase block height and depth of sympathetic blockade (Nagelhout et al, 2013, p. 1129).

Physiological changes that occur during pregnancy can also predispose patients to hypotension. Pregnant women at term or near-term may be at risk for supine hypotension syndrome, also known as aortocaval compression, which is caused by vena cava and aorta compression by the gravid uterus. Aortocaval compression occurs mainly in the supine position when the uterus lies vertically on the aorta and vena cava which run concurrently along the spine. The partial occlusion of the great vessels can cause a decrease in venous return, decreases in stroke volume and resulting decreases in cardiac output (Nagelhout et al, 2013). There is an accompanying loss of arteriolar tone, which is why despite numerous prophylactic options to prevent hypotension, vasopressors are the most important treatment (Mercier et al, 2013). Physiological responses to compression of the vena cava and aorta are increases in heart rate and vasoconstriction of lower extremities, however the sympathectomy produced by spinal anesthesia may affect these compensatory responses which can further contribute to hypotension (Nagelhout et al, 2013). Prevention of aortocaval compression is accomplished by left uterine displacement, commonly accomplished by manual displacement, or by left lateral tilt, either with pillow support or a 15-degree tilt of the operating room table. This prophylactic treatment is universally recommended to prevent a decrease in blood pressure and subsequent drop in venous return and collapse of cardiac output (Mercier et al., 2013). 


\section{Maternal and fetal effects of hypotension.}

Maternal hypotension, if left untreated can progress to unconsciousness, total cardiovascular collapse, and fetal compromise due to uteroplacental hypoperfusion (Nagelhout et al., 2013 p 1143). Maternal effects of unmanaged hypotension can be mild; nausea and vomiting, or progress to more severe side effects if left untreated. Severe side effects could include altered levels of consciousness, aspiration into pulmonary airways, decreased respiratory drive and eventual cardiac arrest (Patel, Shashank \& Shivaramu, 2018). Adequate blood pressures are critical to maintain perfusion of vital organs such as heart, brain, lungs, liver, kidneys and the uterus (Nagelhout et al., 2013).

A fetal side effect of maternal hypotension is uteroplacental hypoperfusion. Maternal-fetal gas exchange is highly dependent on uterine and placental blood flow, which is maintained by maternal cardiac output (Stewart et al., 2010). In normal adult circulation, waste products of aerobic metabolism such as carbon dioxide are exhaled and exchanged for oxygen, thus regulating the acid-base balance within the body. The fetus is unable to exhale and is thus dependent on maternal circulation for the delivery of oxygen, and after fetal metabolism the excretion of waste products (Fahey \& King, 2010). Uterine and placental hypoperfusion impacts fetal gas exchange which can create a state of anaerobic metabolism within the fetus. Without oxygen exchange, hydrogen ions form organic acids such as lactic acid which negatively impacts the fetal acid-base balance (Nagelhout et al., 2013; Fahey \& King, 2010). Normally adult pH is within the range of 7.35-7.45 while normal umbilical artery $\mathrm{pH}$ of newborns is 7.25-7.30 indicating fetal homeostasis is maintained at a slightly more acidotic $\mathrm{pH}$ (Thorp, Sampson, Parisi \& Creasy, 1989). 
The natural progression of labor can produce transient periods of uteroplacental hypoperfusion as the uterus contracts and interrupts normal blood circulation through the placental barrier. Adaptive mechanisms for the fetus will maintain normal hemostasis during these events, however when low perfusion states are prolonged such as during maternal hypotension it can lead to fetal hypoxia. An increase in hydrogen ions from lack of oxygen exchange will cause a decrease in fetal $\mathrm{pH}$ and respiratory acidosis. Subsequently if hypoxemia and hypoxia continue, anaerobic metabolism will begin producing lactic acid causing metabolic acidosis (Fahey \& King, 2010). Post-partum neonatal umbilical cord blood $\mathrm{pH}$ is routinely tested and is used as a predictor of fetal outcomes. A 2019 study by Rimsza, Perez, Babbar, O’brien and Vricella investigated the correlation between time of neuraxial placement to neonatal delivery and the effects of umbilical arterial cord $\mathrm{pH}$ and found that maternal hypotension was one of the predictive factors of decreasing neonatal $\mathrm{pH}$ levels. Cases with extended start times had lower umbilical arterial $\mathrm{pH}$ along with lower venous $\mathrm{pH}$ and elevated $\mathrm{pCO} 2$ levels which is consistent with fetal respiratory acidemia (Rimsza et al., 2019). Cases may have delayed start times for numerous reasons, including but not limited to surgeon delay, operating room availability, supply constraints, staffing issues or complications related to prepping the patient for a procedure.

\section{Interventions for Prevention and Treatment of Hypotension}

Providers use a range of techniques to prevent and treat hypotension; intravenous fluid administration, physical interventions such as uterine displacement or compression devices, and pharmacological treatments (Choi et al., 2017). For several decades, fluid therapy has been the traditional treatment for spinal anesthesia induced hypotension (Lee, 
George \& Habib, 2017). Numerous studies have examined fluid therapy, studying the type of fluids; crystalloid fluid versus colloid fluid, timing of the administration; preloading versus co-loading in regard to timing of the block, and optimal quantities of fluid to be administered. Although fluid administration will increase intravascular space, thereby increasing cardiac output, it is thought that the fluid rapidly redistributes, and rates of hypotension continue to be high (Lee, George \& Habib, 2017). Currently, there is no study that definitively shows that an ideal fluid type or amount will negate maternal hypotension on its own.

As previously discussed, patient positioning can improve blood flow and is an important nonpharmacological intervention for preventing hypotension. While uterine displacement is widely accepted as a nonpharmaceutical intervention, manual displacement of the uterus by the provider appears to have superior efficacy when compared to left lateral tilt of the patients hips or operating room table (Choi et al., 2017). Other techniques such as lower leg compression or elevation of the legs do not appear to be overtly effective, however few studies have examined these techniques and those that did had small cohorts (Choi et al., 2017).

Vasopressors have been found to be the most important intervention in the treatment of maternal hypotension (Mercier et al., 2013). Ephedrine, a synthetic indirectacting sympathomimetic that has both alpha- and beta-adrenergic receptors, was historically the vasopressor of choice (Nagelhout et al, 2013). A shift away from ephedrine occurred after increasing evidence showed that ephedrine crosses the placenta barrier with an associated decrease in umbilical arterial $\mathrm{pH}$ and base excess (Ngan Kee, Shaw, Tan, Ng, \& Karmaker, 2009). Phenylephrine is currently the established 
vasopressor for treatment and prevention of maternal hypotension (Nagelhout et al., 2013). Recently, evidence has shown that phenylephrine has the propensity to decrease maternal heart rate and cardiac output which could potentially have deleterious effects to the fetus (Stewart et al., 2010). As a result, there has been a renewed interest in alternative vasopressors such as norepinephrine to treat maternal hypotension.

\section{Phenylephrine}

Phenylephrine (Neo-synephrine) is a direct-acting sympathomimetic amine that has $\alpha_{1}$-adrenergic agonist with minimal to no beta-adrenergic affinity. It has FDAapproval for the use of treatment for clinically significant hypotension from vasodilation, such as from neuraxial anesthesia (Richards \& Maani, 2019). It is an ideal vasopressor because it has a quick onset, short duration, and has expected dose-dependent responses. Intravenous (IV) phenylephrine has potent vasoconstriction properties which can increase preload, systemic vascular resistance and afterload. However, phenylephrine's stimulation of alpha-adrenergic receptors only can lead to baroreceptor-mediated reflex bradycardia (Richards \& Maani, 2019). This decrease in heart rate and consequent decrease in cardiac output raises concern over uteroplacental perfusion side effects (Carvalho \& Dyer, 2015).

\section{Norepinephrine}

Norepinephrine is a sympathomimetic amine which primarily works as an $\alpha_{1-}$ adrenergic agonist with $\beta_{1}$-agonist with mild to no effect on $\beta_{2}$ or $\alpha_{2}$ receptors. Structurally it is identical to epinephrine, but a lack of methyl group on its nitrogen atom affects its site of action. It is FDA-approved for blood pressure control during acute hypotensive states and is commonly the first line agent for treating hypotension during 
septic shock (Smith \& Maani, 2019). Norepinephrine has strong vasoconstricting properties with less potent direct inotropic abilities and minimal chronotropic effects which is beneficial for patients whose heart rate stimulation is unwarranted (Overgaard \& Džavik, 2008). Norepinephrine primarily increases both systolic and diastolic blood pressures, with an increase to pulse pressure and a minimal net impact on patients' cardiac outputs (Overgaard \& Džavik, 2008).

Due to norepinephrine's strong vasoconstricting properties, concern exists for potentially severe complications if administered through a peripheral venous catheter. Complications include extravasation, thrombophlebitis, localized cellulites, and tissue necrosis (Nagelhout et al., 2013). A recent observational study investigated the complications from vasopressor administration via peripheral venous catheters. Significant morbidity was not established, and the authors found that administration of norepinephrine through peripheral IVs for a median duration of 13 hours [interquartile range of 6.5-31.5 hours] had a low rate (5.5\%) of minor complications which did not require any intervention (Medlej et al., 2017). It is still recommended that instillation of norepinephrine should be through a large-bore peripheral catheter, ideally in the antecubital vein or through a central venous catheter.

The use of norepinephrine as an alternative to phenylephrine for the treatment of maternal hypotension is a relatively novel idea. In the United States norepinephrine's area of use is typically the intensive care unit or in cardiac anesthesia while phenylephrine is a commonly used medication readily available in the operating room. The possible future use of norepinephrine could be met with logistical and culture resistance (Carvalho \& Dyer, 2015). Despite possible resistance, it is worth investigating 
norepinephrine as a potential alternative to phenylephrine due to its lower incidence of bradycardia and minimal decreases in cardiac output.

Next the frameworks used to guide this review will be discussed. 


\section{Theoretical Framework}

The PRISMA framework was used as the theoretical framework for this systematic review. The Preferred Reporting Items for Systematic Reviews and MetaAnalyses (PRIMSA) Statement was developed from the QUOROM Statement (Quality of Reporting of Meta-Analyses) which was developed in 1996 (Moher, Liberarti, Tetzlaff, Altman, \& The PRISMA group, 2009). The updated and revised PRISMA Statement addresses multiple advances that have been made in the science among systematic reviews (Moher et al., 2009). The goal of PRISMA is to aid investigators in their assessment of systematic reviews and aid in the writing of a systematic review using a flow diagram and checklist. The use of PRISMA ensures increased transparency among systematic reviews and aims to minimize potential bias from study selection.

The PRISMA Statement includes a 27-item checklist (Appendix A) and includes seven major categories: title, abstract, introduction, methods, results, discussion, and funding. Subheadings within the major categories go on to describe the checklist item in further detail. In addition to the checklist, The PRISMA Statement also consists of a four-phase flow diagram (Figure 1), illustrated on the next page. The flow diagram helps guide the identification, screening, eligibility and inclusion or exclusion of research studies (Moher et al., 2009). The comparative use of norephedrine versus phenylephrine to prevent or in treatment of maternal hypotension is a recent idea with limited research. The current, available randomized controlled trials were assessed utilizing the PRIMSA checklist to aid in inclusion and exclusion of randomized control trials. 


\section{PRISMA 2009 Flow Diagram}

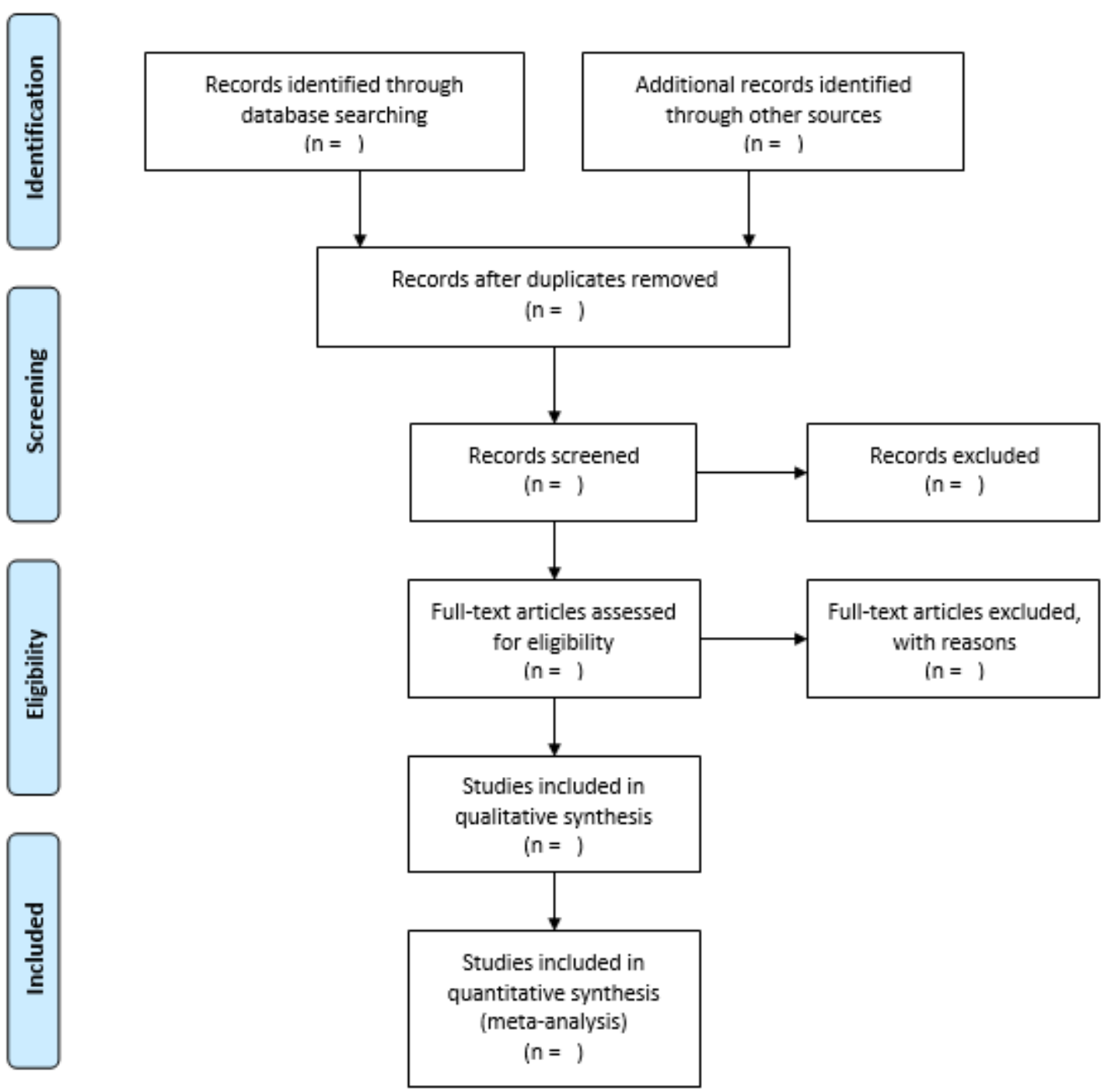

Figure 1. PRISMA 2009 Flowchart (Moher et al., 2009) 


\section{Method}

\section{Purpose}

The purpose of this paper was to conduct a systematic review to investigate the use of norepinephrine versus phenylephrine for the treatment of maternal hypotension during spinal anesthesia for cesarean delivery.

\section{Inclusion and Exclusion Criteria}

Inclusion criteria was randomized control trials that investigated the use of phenylephrine and/or norepinephrine for the treatment of maternal hypotension during spinal anesthesia for cesarean delivery. Studies published between January 2009 to December 2019 that include women 18-55 years of age undergoing scheduled or emergent cesarean delivery were included. Women with past medical histories of preeclampsia were also included. Outcomes included were maternal hemodynamics; HR, $\mathrm{CO}, \mathrm{BP}$, and fetal outcomes; Apgar score, $\mathrm{pH}$ and umbilical blood gases. Exclusion criteria was studies published before 2009 and those not in the English language, and studies involving non-cesarean delivery use of phenylephrine or norepinephrine.

\section{Search Strategy}

The search was conducted using the databases CINAHL, MEDLINE, Google Scholar and PubMed. The terms searched were Phenylephrine, Norepinephrine, spinal anesthesia, maternal hypotension, low blood pressure, cesarean delivery and/or c-section, complications, fetal compromise and randomized control trial. The planned search was limited to the above-mentioned inclusion criteria. The PRISMA flowchart and checklist were used to evaluate and validate selected randomized control trials. 


\section{Data Collection}

Data collected through the above methods was organized in a data collection table, depicted below (Table 1). The study characteristics included in each table were the studies purpose, sample/setting, anesthesia provided, interventions, outcomes and any limitations within the study. Tables were completed for each randomized control trial selected for this study and analyzed for relevant data (Appendix C).

Table 1

Data Collection Table

\begin{tabular}{|l|l|l|l|l|}
\hline Citation: \\
\hline $\begin{array}{l}\text { Purpose \& } \\
\text { Sample/Setting }\end{array}$ & Anesthesia & Intervention & Outcomes & Limitations \\
\hline & & & & \\
\hline
\end{tabular}

\section{Critical Appraisal}

The Critical Appraisal Skills Program (CASP) checklist was utilized to critically appraise the randomized control trials selected for this systematic review. The 11-item CASP checklist was utilized in evaluating the results of each randomized control trial and identifying any limitations or biases within the studies. CASP considers three issues when considering and appraising a trail: Are the results valid, what are the results, and will the results help locally? The first three questions are progressive and if the answer is "yes" it is suggested to proceed to the remaining questions. Most of the remaining questions may be answered with a "yes," "no," or "can't tell (CASP, 2018)." The CASP checklist was completed for each randomized control trial selected for this systematic review (Appendix C). 
CASP Checklist

A. Are the results of the trial valid?

YES CAN'T NO

TELL

1. Did the trial address a clearly focused issue?

2. Was the assignment of patients to treatments randomized?

3. Were all of the patients who entered the trial properly accounted for at its conclusion?

4. Were patients, health workers, and study personnel "blind" to treatment?

5. Were the groups similar at the start of the trial?

6. Aside from the experimental intervention, were the groups treated equally?

B. What are the results?

7. How large was the treatment effect?

8. How precise was the estimate of the treatment effect?

C. Will the results help locally?

YES CAN'T NO

TELL

9. Can the results be applied in your context?

10. Were all clinically important outcomes considered?

11. Are the benefits worth the harms and costs?

Figure 2. CASP Checklist (CASP, 2018)

\section{Data Synthesis}

A data synthesis table was created to synthesize data extracted from the five selected randomized control trails. A cross study analysis was performed to identify effects of norepinephrine versus phenylephrine for the treatment of maternal hypotension during spinal anesthesia for cesarean delivery. The data was organized into a table with the focus on effects on maternal hypotension, incidence of bradycardia, effects on cardiac output, incidence of nausea and vomiting, neonatal Apgar scores and effects on umbilical cord gases. The data synthesis table (Table 2) was used for cross-study analysis and results will be discussed in detail in the results section of this systematic review. 
Table 2

Data Synthesis Table

\begin{tabular}{|l|l|l|l|l|l|l|l|}
\hline Author, & $\begin{array}{l}\text { ASA } \\
\text { Year } \\
\text { Classification } \\
\text { C Patient } \\
\text { Characteristics }\end{array}$ & $\begin{array}{l}\text { Incidence of } \\
\text { Maternal } \\
\text { Hypotension }\end{array}$ & $\begin{array}{l}\text { Maternal } \\
\text { Cardiac } \\
\text { Output }\end{array}$ & $\begin{array}{l}\text { Incidence } \\
\text { of } \\
\text { Bradycardia }\end{array}$ & $\begin{array}{l}\text { Incidence of } \\
\text { intraoperative } \\
\text { nausea/vomiting }\end{array}$ & $\begin{array}{l}\text { Neonatal } \\
\text { Apgar } \\
\text { Scores }\end{array}$ & $\begin{array}{l}\text { Umbilical } \\
\text { Cord } \\
\text { Gases }\end{array}$ \\
\hline & & & & & & & \\
\hline
\end{tabular}

Next, the results section will be discussed. 


\section{Results}

A database search was conducted and a total of 15 non-duplicate citations were screened. The completed PRISMA diagram shows the elimination of citations (Figure 3). The titles and abstracts were reviewed for inclusion or exclusion criteria and 7 articles were excluded based off preliminary analysis. One article was excluded after data extraction. The five remaining articles were reviewed completely, and inclusion and exclusion criteria were again applied with no articles needing to be eliminated. The five articles were included in this systematic review.

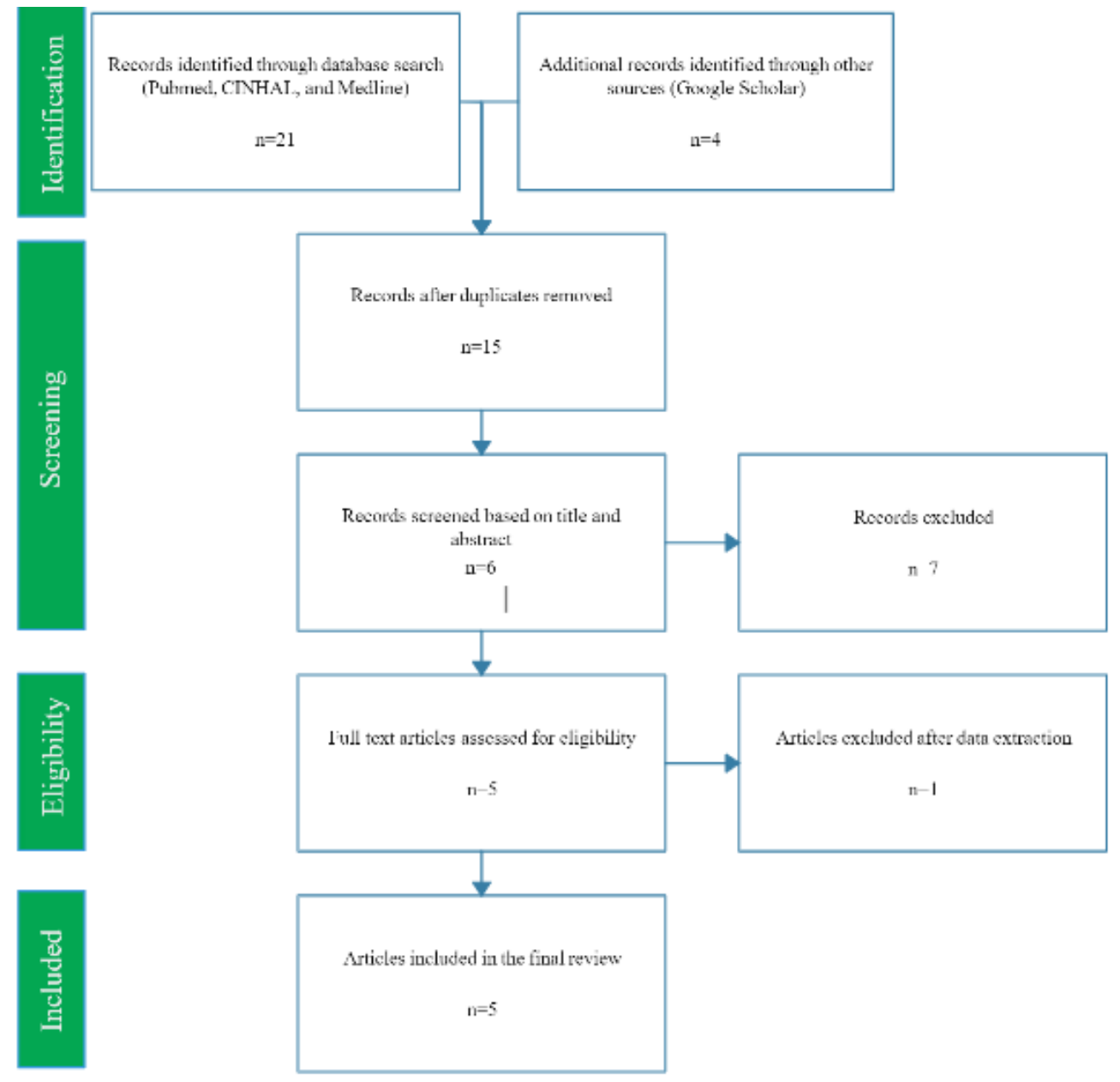

Figure 3. Completed PRISMA flow diagram demonstrating article screening, inclusion or exclusion and final results. 


\section{Individual Study Analysis}

In 2015, Ngan Kee et al. published the landmark RESPOND study, a randomized control study evaluating the use of phenylephrine verses norepinephrine for the maintenance of blood pressure after spinal anesthesia for cesarean delivery (Appendix B1). The study compared the use of computer-controlled closed loop infusions of the study drugs for the maintenance of maternal blood pressure. The primary outcomes assessed were maternal heart rate (HR) and cardiac output $(\mathrm{CO})$. Secondary outcomes were neonatal outcomes and assessment of umbilical cord gases.

Sample size was calculated based on the authors previously published and unpublished studies which evaluated hemodynamic data from obstetric patients. A sample size of 47 patients per group was calculated to have a larger than $90 \%$ power to detect a $20 \%$ change in $\mathrm{CO}$ between study groups five minutes after intrathecal injection with an $\alpha$ error probability of 0.05 . Polynomial data was analyzed using the KolmogorovSmirnov test and cross analyzed using Student t test or the Mann-Whitney U test. Nominal data was assessed using the chi-square test of the Fisher exact test. Values for $\mathrm{CO}$, stroke volume (SV), and systemic vascular resistance (SVR) were measured noninvasively using suprasternal Doppler and values were normalized to percentage of baseline. Due to the variable times to complete measurements for HR and systolic blood pressure (SBP) data was grouped according to chronological recording.

Initially 104 women were recruited into the Ngan Kee et al., (2015) study. Exclusion data was applied and 49 patients were randomized into the norepinephrine group (group N) and 52 patients into the phenylephrine group (group P). Patients 
received standardized treatments upon study admittance and patient characteristics and surgical times were comparable between groups. All patients were fasted the night prior to the c-section and received prophylactic antacid medications. On arrival to the operating room baseline hemodynamics were recorded with pulse oximetry, electrocardiography, and non-invasive blood pressure with mean arterial blood pressures (MAP) being calculated from the latter. $\mathrm{CO}, \mathrm{SV}$, and SVR were also obtained and repeated three times for baseline value. All hemodynamics were measured by an experienced operator who was blinded to patient group assignment.

After a large-bore intravenous cannula was placed all patients received standardized spinal anesthesia in the right lateral position. Infusion of study drugs was started at the time of intrathecal injection. A solution of either norepinephrine $5 \mathrm{mcg} / \mathrm{ml}$ or phenylephrine $100 \mathrm{mcg} / \mathrm{ml}$ was administered from prepared $50-\mathrm{mL}$ syringes that were labeled "study drug." The concentration of norepinephrine $5 \mathrm{mcg} / \mathrm{mL}$ or phenylephrine $100 \mathrm{mcg} / \mathrm{mL}$ were thought to be equipotent at a ratio of $20: 1$ based on previous comparative studies done by Sjöberg, Andersson, and Steen (1989). The study drug administration was regulated using a computer-controlled closed-loop feedback system based off the patients SBP which was set to cycle every 1 minute. The infusions were initially started at $30 \mathrm{~mL} /$ hour and after completion of the first SBP measurement the rate was adjusted based off the computer algorithm. Administration rates were limited to 0-60 $\mathrm{mL} /$ hour (range of $0-5 \mathrm{mcg} / \mathrm{minute}$ of norepinephrine and $0-100 \mathrm{mcg} / \mathrm{minute}$ of phenylephrine) and defaulted to a rate of $0 \mathrm{~mL} /$ hour if the patients $\mathrm{HR}$ was $<50$ beats per minute (bpm). Endpoint was set at the time of neonatal delivery. 
Serial hemodynamics were monitored throughout the cesarean delivery; BP and HR were set for 1-minute cycle times, while CO, SV, and SVR were measured in 5minute intervals. Of note, one patient from group $\mathrm{N}$ required supplemental oxygen for a pulse oximeter reading $<95 \%$. After delivery, the neonate's Apgar score was assessed by a midwife at the 1-minute and 5-minute post-delivery mark. Samples of umbilical arterial (UA) and umbilical venous (UV) blood were collected from a double-clamped stretch of the umbilical cord. Samples with insufficient blood quantity or equipment failure were accounted for within the study.

The study outcome concluded that maternal SBP was maintained similarly between study groups, but norepinephrine use correlated with a greater HR and $\mathrm{CO}$ with a lower SVR. It found that $\mathrm{CO}$ at the five-minute point was higher in group $\mathrm{N}$ versus group $\mathrm{P}$, with a $\mathrm{P}$ value of 0.004 . SVR was lower in the group $\mathrm{N}$ when compared to group $\mathrm{P}(\mathrm{P}<0.001)$. Group $\mathrm{N}$ rates of bradycardia (defined as a $\mathrm{HR}<60 \mathrm{bpm}$ ) were less then group $\mathrm{P}(18.4 \%$ vs $55.8 \%, \mathrm{P}<0.001)$. There was no difference in $\mathrm{SV}$ between groups $(\mathrm{P}=0.44)$. Ngan Kee et al., attributed the greater $\mathrm{CO}$ in group $\mathrm{N}$ to be primarily related to the lower incidence of bradycardia since CO is based off a patients HR and SV. UV pH and $\mathrm{UV}$ oxygen content were higher in group $\mathrm{N}$ which the authors attributed to the greater placental blood flow theoretically from the increase in CO. Neonatal outcomes were found to be otherwise similar between groups. The authors concluded that norepinephrine and phenylephrine have similar efficacy for the maintenance of blood pressure following spinal anesthesia for cesarean delivery, but norepinephrine maintained greater maternal $\mathrm{HR}$ and $\mathrm{CO}$. The authors suggested further studies would be warranted 
to investigate norepinephrine and its safety for use among obstetric patients, modes of administration, and relative potency of norepinephrine versus phenylephrine.

The 2019 study by Wang, Mao, Liu, Xu \& Yang, compared the efficacy and safety of bolus dose norepinephrine, phenylephrine and ephedrine for the treatment of hypotension during cesarean delivery under spinal anesthesia for parturients with preeclampsia (Appendix B-2). The primary outcome measured was maternal SBP and HR. Secondary outcomes assessed were incidence of tachycardia, bradycardia, and hypertension. The amount of vasopressor required, number of hypotensive episodes, maternal side effects and neonatal outcomes were also analyzed.

Wang et al., enrolled parturients between January and June of 2018 at a hospital in Nanjing, China. Sample size was calculated based off a pilot study that examined the rates of tachycardia with the use of norepinephrine or ephedrine treating parturients with preeclampsia. A minimum of 49 cases per group was calculated to detect a statistically significant difference in rates of tachycardia between groups. The sample size was increased to 55 patients per group to account for possible drop out. Univariate data was analyzed using D’Agostino-Pearson omnibus normality test and one-way analysis of variance (ANOVA) and then by a two-sample t-test or Mann-Whitney test. Nominal data was analyzed using a chi-squared test or Fisher's exact test. A p-value of $<0.05$ was considered to be statistically significant.

A total of 368 women were initially recruited into the study. After inclusion and exclusion criteria was applied 315 patients were randomized into the three study groups. Only patients who had successful spinal anesthesia and those who developed hypotension 
were included in the final analysis. Final enrolled participants included 56 patients allocated to the norepinephrine group (group N), 55 patients to the phenylephrine (group P) and 55 patients to the ephedrine (group E) group. Inclusion criteria was American Society of Anesthesiologist (ASA) status I-II, singleton pregnancy scheduled for spinal anesthesia and included a diagnosis of pre-eclampsia. Pre-eclampsia was defined as at least two BP readings of $\geq 140 / 90 \mathrm{mmHg}$ in a four-hour interval, with a 24-hour proteinuria of $\geq 300 \mathrm{mg}$ or $\geq 1+$ with a dipstick. Parturients with severe pre-eclampsia were also included in the study. Severe pre-eclampsia was defined as a BP reading of $\geq 160 / 110$ with any of the following comorbidities; low platelets, cerebral or visual disturbances, pulmonary edema, altered liver function and impairment of renal function.

Patients received standardized treatment regarding anesthesia and study medication administration. Upon entering the operating room, participants were positioned in supine, left uterine displacement position and three consecutive readings of $\mathrm{BP}, \mathrm{HR}$, and pulse oximetry were taken for baseline value. An independent researcher recorded all maternal hemodynamic values; BP and HR were recorded every minute from intrathecal anesthesia instillation until neonatal delivery. Patients were positioned in the left lateral position and received an intrathecal injection of 2.0-2.2 $\mathrm{ml}$ of hyperbaric bupivacaine $0.5 \%$. Immediately following injection, patients were returned to the left uterine displacement supine position and received Ringer's lactate hydration at a maximum rate of $10 \mathrm{ml} / \mathrm{kg}$. Hypotension following intrathecal injection was defined as an SBP $<80 \%$ of patients baseline readings and treatment was administration of the selected study drug. Based off group assignment, patients received either norepinephrine $4 \mathrm{mcg}$, phenylephrine $50 \mathrm{mcg}$, or ephedrine $4 \mathrm{mg}$. Atropine $0.5 \mathrm{mg}$ intravenously was injected for 
bradycardia, defined as a HR of $<60 \mathrm{bpm}$. The study endpoint was delivery of the neonate. After delivery umbilical artery blood was collected from a double-clamped cord and a pediatrician evaluated the neonate using the Apgar scoring system at one minute and five minutes. Blood gases that could not be accounted for due to insufficient blood samples or equipment failure were accounted for within the groups.

Due to the diagnosis of pre-eclampsia, multiple patients within the study groups were receiving antihypertensive treatments (group $\mathrm{N} \mathrm{n}=42$, group $\mathrm{P} n=40$, group $\mathrm{E} n=40$ ). Ten women in group $\mathrm{N}$, twelve women in group $\mathrm{P}$, and eight women in group $\mathrm{E}$ were diagnosed with severe pre-eclampsia. Within those diagnosed with severe pre-eclampsia, six in group $\mathrm{N}$, five in group $\mathrm{N}$, and five in group $\mathrm{E}$ received magnesium sulfate as a prophylaxis against seizures, a risk of severe pre-eclampsia. Of note, not included in the study was the type of antihypertensive patients were prescribed or if those medications could have affected study medications administered.

The outcome of Wang et al., 2019 study into the efficacy and safety of bolus norepinephrine, phenylephrine, and ephedrine concluded that overall all three medications were effective in the treatment of spinal hypotension in pre-eclamptic women (Appendix D). However, group $\mathrm{N}$ was found to be superior to other study medications at maintaining HR. Group $\mathrm{N}$ had less incidence of tachycardia (defined as a HR $>120 \mathrm{bpm})$ when compared to group $\mathrm{E}(16.1 \%$ vs $36.4 \% ; \mathrm{P}=<0.05)$ and less incidence of bradycardia when compared to group $\mathrm{P}(3.6 \%$ vs $21.8 \% ; \mathrm{P}=<0.004)$. No statistical difference was found between groups in the number of hypotensive episodes, the number of boluses required, or the incidence of hypertensive episodes. Incidence of intraoperative nausea and vomiting (IONV) was found to be lower in group N (5.4\%) 
versus group E (20\%) $(\mathrm{P}=0.02)$. Neonatal Apgar scores were similar among groups and no neonate had an Apgar score of $<9$ at the five-minute assessment. Fetal UA pH was higher in group $\mathrm{N}$ versus group $\mathrm{E}$ ( $7.32 \pm 0.02$ vs $7.31 \pm 0.031 ; \mathrm{P}=0.006)$. Among the groups, no neonate had fetal acidosis, defined as an $\mathrm{UA} \mathrm{pH}<7.20$. UA lactate was also found to be lower in group $\mathrm{N}(1.3 \pm 0.3)$ verses group $\mathrm{E}(1.8 \pm 0.5)(\mathrm{P}=<0.001)$. No statistically significant differences were found in the UA blood gases between groups $\mathrm{N}$ and $\mathrm{P}$. The authors concluded that while norepinephrine had similar efficacy for the maintenance of SBP when compared to the other study drugs, it had an improved maternal safety profile when compared to phenylephrine. They also stated that norepinephrine had an improved maternal and neonatal safety profile when compared with ephedrine.

The 2017 study by Vallejo et al., compared the use of prophylactic infusions of phenylephrine versus norepinephrine for the maintenance of systolic blood pressure during cesarean delivery under spinal anesthesia (Appendix B-3). The primary outcome measured was the number and total dose of rescue boluses needed to maintain SBP in addition to the study drug infusion. Secondary outcomes measured were maternal hemodynamics; HR, CO, cardiac index (CI), SV, and SVR. Fetal outcomes such as Apgar score at 1 minute and 5 minute and umbilical cord blood gases were also analyzed of obtained as part of the neonate's routine care.

The Vallejo et al., study enrolled 85 patients into their study between August 2014 and August 2015. The authors calculated sample size based off a local pilot study which indicated that 35 parturients were required per group to detect a decrease to $10 \%$ in the rates of maternal hypotension at the 0.05 significance level with $80 \%$ power. Overall 
study size was increased to 85 patients to account for dropout. A two-sample Z-test was utilized to analyze the difference between groups in the number of patients requiring at least one rescue bolus. Nominal data for secondary outcomes was analyzed using the chisquared test. Hemodynamic parameters and trends were analyzed using multivariate analysis of variance (MANOVA). A P value of $<0.05$ was considered to be significant.

Patients were randomized to two treatment groups using a computer-generated table. Group one (group P, n=38) received a fixed rate infusion of $0.1 \mathrm{mcg} / \mathrm{kg} / \mathrm{min}$ phenylephrine while group two (group $\mathrm{N}, \mathrm{n}=39$ ) received $0.05 \mathrm{mcg} / \mathrm{kg} / \mathrm{min}$ norepinephrine also at a fixed rate. Inclusion criteria included an ASA status of $<$ III, $>36-$ week singleton pregnancy with a BMI $<40 \mathrm{~kg} / \mathrm{m}^{2}$. Patient characteristics and demographics were similar between both study groups. All patients were accounted for at the conclusion of the study and once enrolled patients received standardized treatment.

All patients had preoperative SBP and HR measured three times consecutively and averaged for a baseline. Prior to entering the operating room study participants received $500 \mathrm{~mL}$ of lactated Ringers solution intravenously. Upon entering the operating room, patients received a standardized spinal anesthetic in the sitting position consisting of hyperbaric bupivacaine $12-15 \mathrm{mg}$ with an opioid adjunct of fentanyl $20 \mathrm{mcg}$ and preservative-free morphine $0.2 \mathrm{mg}$ intrathecally. The selected study drug, which was made aware to the anesthesia provider upon patient arrival, was started at the time of intrathecal injection. Hypotension was defined as a decrease below $100 \%$ of baseline and was treated with a rescue bolus of $100 \mathrm{mcg}$ phenylephrine. Bradycardia as defined as a $\mathrm{HR}<60 \mathrm{bpm}$ was treated by infusion discontinuation and if compounded with hypotension was treated with a rescue bolus of $5 \mathrm{mg}$ of ephedrine. Infusions were held 
for any episodes of hypertension, as defined by an SBP $>120 \%$ of baseline.

Hemodynamics were continuously recorded using a non-invasive hemodynamic monitor. The study endpoint was at the point of transfer of care back to labor and delivery postoperatively.

The study by Vallejo et al., concluded that prophylactic fixed-rate infusions of norepinephrine were efficacious for the prevention of hypotension after spinal anesthesia during cesarean delivery. The study found no difference between groups in study drug infusion length, incidence of bradycardia, or non-invasive hemodynamic parameters (HR $\mathrm{P}=0.17, \mathrm{CO} \mathrm{P}=0.5, \mathrm{SVR} \mathrm{P}=0.54$ ). The number of patients who received $\geq 1$ rescue bolus of phenylephrine was similar between groups (Group P 52.6\% vs group N $46.5 \%$, $\mathrm{P}=0.58$ ). However, the use of $\geq 1$ bolus of rescue dose ephedrine was higher in group $\mathrm{P}$ (23.7\%) in comparison to group $\mathrm{N}(2.3 \%)(\mathrm{P}<0.01)$. Overall incidence of IONV was similar between groups however the incidence of emesis was greater in group P (26.3\%) than in group $\mathrm{N}(1.63 \%)(\mathrm{P}<0.001)$. No statistically significant difference was found in fetal Apgar scores $<7$ at 1 minute $(\mathrm{P}=0.82)$ or 5 minutes $(\mathrm{P}=0.48)$ and $\mathrm{UV} \mathrm{pH}$ were similar between groups $(\mathrm{P}=0.42)$. The authors concluded that norepinephrine infusions can be considered as an alternative to phenylephrine however future research is required to analyze its overall safety.

The 2018 randomized control trial by Sharkey et al., investigated the use of bolus dose phenylephrine verses norepinephrine to prevent and treat hypotension during cesarean delivery (Appendix B-4). The primary outcome assessed was rate of maternal bradycardia as defined as a HR $<50 \mathrm{bpm}$. Secondary outcomes assessed included the incidence of maternal hypotension or hypertension, incidence of tachycardia, and 
episodes of nausea and/or vomiting. Fetal outcomes were also assessed through umbilical gas analysis, and fetal Apgar scores.

Study sample size was calculated based on two previously conducted studies by Sharkley et al., research group. A sample size of 112 total participants was estimated to achieve $80 \%$ power to detect a $70 \%$ decrease in the episodes of bradycardia in each group with a significance level of 0.05 . The goal of 56 participants per group accounted for an anticipated 5\% withdrawal rate. Data for the primary outcome, bradycardia, was analyzed using the ${ }^{2}$ test. Secondary outcomes were compared using the ${ }^{2}$ test or the Fisher exact test for categorical variables, and the Student $t$ test or Wilcoxon rank sum test, when appropriate for continuous variables. A P value of $<0.05$ was considered to be statistically significant.

Between January 3, 2017 and April 17, 2017 Sharkey et al., enrolled 112 eligible parturients to be placed evenly into two treatment groups. Patients were randomized into their respective treatment groups using computer generated block randomizations. Group one, (group $\mathrm{P}, \mathrm{n}=56$ ) received a standard dose of phenylephrine $100 \mathrm{mcg}$ while group two (group $\mathrm{N}, \mathrm{n}=56$ ) received a standard dose of norepinephrine $6 \mathrm{mcg}$. The study drugs were administered manually by an anesthesia provider, who was blinded to group allocation, to prophylactically prevent or treat hypotension as defined as an SBP $<80 \%$ baseline value. Inclusion criteria for study participants included an ASA status of $\leq \mathrm{III}$, singleton term pregnancy with a weight between 50-100kg. Patients received standardized treatments upon study admittance and patient characteristics were similar between the two treatment groups. All patients had preoperative SBP and HR measured three times one minute apart for baseline values. Upon entering the operating room, patients were connected to 
standard monitoring equipment and positioned in the sitting position. Standardized spinal anesthesia was administered in the L3/4 interspace as identified by ultrasound. Immediately after intrathecal injection patients were coloaded with $10 \mathrm{~mL} / \mathrm{kg}$ (maximum of 1 liter) of lactated Ringer's infusion via pressure bag infusion. Patients were positioned left lateral tilt and SBP, HR and pulse oximetry were monitored every 1 minute for the duration of the study which continued from the time of intrathecal injection to the delivery of the fetus. Selected study drugs could be administered as often as one minute prophylactically or for any episode of hypotension. Rescue boluses of ephedrine 10mg were administered for any hypotensive episodes coinciding with a HR $<60$ or for any hypotensive episodes lasting more than 2 consecutive BP readings regardless of study drug administration.

The study outcome by Sharkey et al., concluded that intermittent bolus doses of norepinephrine to prevent hypotension during cesarean delivery had a lower incidence of bradycardia when compared to bolus dose phenylephrine (Appendix D). The rate of bradycardia was lower in group N when compared to Group P (10.9\% vs. $37.5 \%$; $\mathrm{P}=<0.001$ ) which implied a relative reduction of $71 \%$. Using the $\quad{ }^{2}$ test to analyze the data, it was found that patients in group P had a higher risk of having multiple episodes of bradycardia when compared to group $\mathrm{N}(\mathrm{P}=0.008)$. While there was no statistical difference between groups regarding rates of hypotension $(\mathrm{P}=0.9)$, the incidence of patients requiring rescue boluses of ephedrine for 2 consecutive hypotensive SBP readings was higher among group $\mathrm{P}(21.4 \%)$ verses group $\mathrm{N}(7.2 \%)(\mathrm{P}<0.3)$. Rates of nausea and vomiting were similar between groups ( $\mathrm{P}=0.57, \mathrm{P}=0.17$ respectively). Fetal outcomes were comparable between groups; no Apgar score was $<7$ at 1-minute or 5- 
minute assessments for either group. There was no statistical difference in umbilical arterial or venous blood gases between the two groups. The authors concluded that phenylephrine and norepinephrine had similar efficacy for the maintenance of maternal blood pressure during spinal anesthesia for cesarean delivery, however norepinephrine had a lower incidence of bradycardia.

The 2019 randomized control trial by Mohta, Garg, Chilkoi and Malhotra investigated the use of phenylephrine verses norepinephrine for the treatment of hypotension following spinal anesthesia for caesarean section (Appendix B-5). The primary outcome measured was rates of maternal bradycardia following study drug administration. Secondary outcomes were overall blood pressure changes, study drug requirements, maternal complications, and neonatal outcomes.

Mohta et al., recruited 90 parturients between December 2016 to January 2018. All patients who entered the trial were properly accounted for throughout the study. Inclusion criteria was a singleton, uncomplicated, term pregnancy. Participants were randomized into group allotments via a computer-generated random number table and investigators, anesthesia providers and patients were blinded to group allotment. Study recruitment size was based off a previously done study by Mohta et al., which found that a sample size of 45 patients per group would show a clinically significant $60 \%$ decrease in incidence of bradycardia with norepinephrine with a power of $80 \%$ at a 0.05 significance level. Primary study data was analyzed with the Fisher's exact test. Hemodynamic and other parameters were tested by the Shapiro-Wilk test as appropriate. Normally distributed variables were analyzed using the unpaired students t-test. Nonnormal variables, such as episodes of hypotension, vasopressor boluses, neonatal Apgar 
scores were analyzed with the Mann Whitney U-test and a $p$ value of $<0.05$ was considered to be significant. SBP and HR were compared with a linear mixed model and a $\mathrm{p}$ value of $<0.01$ was considered significant.

Women enrolled were randomized into two study groups for the Mohta et al., 2019 study. Group one (group P, n=45) received a bolus of 100 mcg of phenylephrine IV for any hypotensive SBP episode, while group two (group N, n=45) received a 5 mcg bolus of norepinephrine. Hypotension was defined as a decrease of $\geq 20 \%$ from SBP baseline or an SBP $<100 \mathrm{mmHg}$. Baseline SBP and HR were obtained upon entering the operating room and based off an average of three consecutive recordings. All participant received Ringer's lactate solution at a rate of $15 \mathrm{ml} / \mathrm{kg}$ via IV which was initiated upon entering the operating room. Standard spinal anesthesia was performed in the sitting position and after administration patients were positioned left uterine tilt supine position. All patients received $40 \%$ oxygen via facemask until fetal delivery. Patients HR and BP were monitored every minute starting after spinal administration and study end point was set at delivery. Patients received the selected study drug for any episode of hypotension as previously defined. Bradycardia was defined as a $\mathrm{HR}$ of $<60 \mathrm{bpm}$ and $0.6 \mathrm{mg}$ IV of atropine could be administered for any episode of bradycardia combined with hypotension or for an absolute HR $<45 \mathrm{bpm}$. Neonatal Apgar scores were assessed at 1 minute and 5 minutes post-delivery. UA and UV blood gases were sampled prior to the baby's first breath via a double clamped segment of umbilical cord.

Finally, Mohta et al., concluded that there was no significant difference in the rates of maternal bradycardia when using phenylephrine or norepinephrine for the treatment of hypotension after spinal anesthesia. Incidence of bradycardia was 
comparable between the group $\mathrm{P}(37.8 \%)$ and group $\mathrm{N}(22.2 \%)(\mathrm{P}=0.167)$. There was no statistically significant difference between groups in the incidence of hypotensive episodes $(\mathrm{P}=0.06)$. However, the total number of vasopressor boluses required to treat hypotensive episodes was higher in group $\mathrm{P}$ than group $\mathrm{N}(\mathrm{P}=0.01)$. Rates of maternal nausea, vomiting and dizziness were comparable between the two groups $(\mathrm{P}=1.00)$. Umbilical blood gases showed higher levels of UA pH in group P (mean 7.29) versus group $\mathrm{N}(7.25)(\mathrm{P}=0.03)$. Fetal levels of bicarbonate and base excess in UA and UV samples were also higher among group P than group N. No significant difference was found between groups regarding Apgar scores at 1 minute or 5 minutes. The study concluded that $100 \mathrm{mcg}$ of phenylephrine and $5 \mathrm{mcg}$ of norepinephrine were similar in their ability to treat hypotension after spinal anesthesia and had no significant difference in incidence of bradycardia. Due to the differences found in umbilical blood gases, the authors concluded that more research is warranted into placental transfer and metabolic effects of norepinephrine.

\section{Cross Study Analysis}

The data synthesis table (Appendix D) demonstrates the key outcomes across the five studies. All five studies were current, randomized control trials that directly compared phenylephrine to norepinephrine, apart from Wang et al., which also compared ephedrine. The method of medication administration varied between studies and included closed loop computer administration, bolus dose administration, or fixed rate infusions. All of the studies investigated the incidence of maternal hypotension and incidence of bradycardia. Maternal cardiac output effects were investigated in two of the five studies; Ngan Kee et al., 2015, and Vallejo et al., 2017. 
Patient characteristics and treatment were comparative throughout the studies except for Wang et al., 2019 which enrolled women with a diagnosis of preeclampsia. All patients included were ASA I-III, singleton, >36-week pregnancies who received spinal anesthesia for scheduled cesarean delivery. Selected spinal anesthesia was single-dose hyperbaric bupivacaine administered into the lumber space. There were variations among the studies regarding the use of narcotics; morphine and/or fentanyl included in the intrathecal anesthesia. Parturients were hydrated with either Hartmann's solution or Ringer's Lactate with dosing ranging from $10 \mathrm{ml} / \mathrm{kg}$ to $2 \mathrm{~L}$ cumulative.

Among the five studies, hemodynamics were monitored throughout the surgical period using a variaty of noninvasive monitors. The definitions of hypotension varied between trials. Hypotension was defined as an SBP $<80 \%$ of baseline in the majority of studies with the exception of Vallejo et al., 2017 which defined it as a decrease of $<100 \%$ of baseline, and Mohta et al., 2019 defined it as a decrease of $\geq 20 \%$ or an absolute value of $<100 \mathrm{mmHg}$. None of the studies found a statistical difference between the rates of hypotensive episodes between the norepinephrine or phenylephrine treatment groups. Cardiac output was monitored in Ngan Kee et al., 2015, and Vallejo et al., 2017. Data was conflicting between the two studies, with Ngan Kee et al., finding that normalized $\mathrm{CO}$ at 5 minutes after spinal anesthesia to be greater within the norepinephrine treatment group and Vallejo et al., 2017 finding no difference between treatment groups. The definition of bradycardia was defined as a heart rate of $<60$ beats per minute in all the studies except Sharkey et al., 2018 which defined it as a heart rate of $<50$ beats per minute. Three of the five studies found the incidence of bradycardia to be lower among the norepinephrine treatment group. 
Maternal incidence of intraoperative nausea and vomiting (N/V) between treatment groups was analyzed among the five trials. Four of the five studies found no statistical difference in rates of N/V between study groups. Vallejo et al., 2017 reported incidence of nausea and vomiting separately and found that while rates of nausea were similar between groups, the incidence of emesis was higher in the phenylephrine intervention group.

Fetal Apgar scores at 1 minute and 5 minutes post delivery were collected in all five trials. All five studies found that Apgar scores were similar between groups at both assessments. Fetal umbilical cord gases were collected in all five trials. After applying the data synthesis table no themes could be obtained between the studies regarding cord gas analysis. Ngan Kee et al., 2015 found that UV pH was greater in the norepinephrine treatment group (mean: 7.35), while Mohta et al., 2019 showed that UA pH was higher in the phenylephrine treatment group (mean: 7.29). UV oxygen content was found to be higher in only one study; Ngan Kee et al., in the norepinephrine intervention group.

Results from the five RCTs included in this systematic review demonstrated that phenylephrine and norepinephrine had similar efficacy in the maintenance of maternal blood pressure following spinal anesthesia. Overall, the incidence of bradycardia was reduced among the norepinephrine group and heart rate was better maintained with norepinephrine versus phenylephrine. The use of norepinephrine was accepted as a possible alternative vasopressor in the obstetric setting but concluded that further research is needed to assess the overall safety of norepinephrine.

Next, the summary and conclusion section will be discussed. 


\section{Summary and Conclusions}

Maternal hypotension is a common occurrence after the administration of spinal anesthesia for cesarean delivery and if left untreated can be dangerous for both mother and fetus. Maternal side effects of untreated hypotension can range from nausea and vomiting, to unconsciousness and eventual cardiac arrest (Nagelhout et al., 2013). Maternal hypotension can impact uteroplacental perfusion and potentially impact the fetus by impairing maternal-fetal gas exchange (Stewart et al., 2010). The mainstay treatment for maternal hypotension is phenylephrine, a direct-acting $\alpha 1$-adrenergic agonist. However, stimulation of $\alpha 1$ receptors can cause a reflexive decrease in heart rate and consequent decrease in cardiac output which theoretically could have a negative impact on fetal wellbeing (Carvalho \& Dyer, 2015; Ryu et al., 2019). Norepinephrine, a vasopressor more commonly used in intensive care units, has $\alpha 1$-adrenergic agonist with mild $\beta 1$-agonist properties and can maintain blood pressure and heart rate, consequently maintaining cardiac output (Nagelhout et al., 2013). The purpose of this paper was to conduct a systematic review into the use of norepinephrine versus phenylephrine for the treatment of maternal hypotension during spinal anesthesia for cesarean delivery.

\section{Using the databases CINAHL, MEDLINE, Google Scholar and PubMed a} comprehensive literature review was conducted using search terms chosen by this author. Many studies were found on the use of the vasopressors ephedrine or phenylephrine, but the use of norepinephrine for treatment of maternal hypotension is a relatively new idea. The lack of comprehensive literature highlighted the need for this systematic review. 
Utilizing inclusion and exclusion criteria, a total of 15 citations were screened through the PRISMA checklist and flow diagram. The five included RCTs selected for this systematic review were also analyzed using the CASP checklist to gauge the validity and results found. Data was collected and organized into data collection tables, and a data synthesis table. Outcomes assessed were maternal hypotension, rates of bradycardia, effects on cardiac output, incidence of nausea vomiting, neonatal Apgar scores and effects on umbilical cord gases. The efficacy of both drugs to maintain maternal blood pressure and preserve heart rate was specifically compared.

All five studies found no difference between medication study groups in rates of hypotensive episodes. Cardiac output was analyzed in two RCTs and resulting data was conflicting; Ngan Kee et al., 2015 found normalized CO at 5 minutes was greater in the norepinephrine group while Vallejo et al., 2017 found no variation between groups. Three out of five studies found that norepinephrine preserved heart rate better than phenylephrine. Maternal and neonatal outcomes were similar between study groups. Only one study found that rates of vomiting were higher among the phenylephrine group, while the other four studies found similar rates of nausea and vomiting between groups. Fetal Apgar scores at 1 minute and 5 minutes were also found to be similar between groups. Unfortunately, no pattern was found among umbilical cord gases; furthering the argument for further study.

There were several limitations to this systematic review. Due to the novelty of the use of norepinephrine in obstetrics, only five studies met inclusion criteria for this systematic review. Among those selected there were variations in drug administration methods, primary outcomes assessed and hemodynamic monitoring throughout the study. 
Further comprehensive research is indicated. Variations in dosage of medications also made direct comparison difficult as well. Ngan Kee et al., 2015 used a potency ratio of 20:1 norepinephrine versus phenylephrine, yet Vallejo et al., 2017 used a potency ratio of $2: 1$. There was no consensus on true potency ratios between studies and further research is warranted. Lastly a potential limitation was that only four databases were searched which could have excluded potential research.

In summary, this systematic review shows that norepinephrine may be considered a possible alternative for phenylephrine for the treatment of maternal hypotension following spinal anesthesia during cesarean delivery. However, further research is warranted into the safety and effects on umbilical cord gases before routine clinical utilization.

Next, the recommendations and implications for advanced nursing practice will be discussed. 


\section{Recommendations and Implications for Advanced Nursing Practice}

Certified Registered Nurse Anesthetists (CRNAs) provide anesthesia to women undergoing cesarean deliveries every day across the nation. A hallmark of the CRNA's practice is the ability to adapt and advance their field by utilizing evidenced-based research. While the occurrence of maternal hypotension is commonly occurring side effect of spinal anesthesia, it can be mitigated and lessened with administration of vasopressors. Administering the superior vasopressor can improve maternal and fetal outcomes.

Phenylephrine is the current first line drug of choice for maternal hypotension, yet as this systematic review demonstrated, it has a propensity to reduce heart rate. Norepinephrine has similar ability to maintain blood pressure without depressing the heart rate which could potentially maintain uteroplacental blood flow better then phenylephrine. The alterations to cardiac output and subsequently uteroplacental blood flow is likely more significant in compromised mothers or fetuses. As previously mentioned, literature is scarce on the use of norepinephrine and the field could benefit from more well-designed, large randomized control trials that include high risk patients. Further study could also demonstrate appropriate potency and ideal method of administration.

For the Advanced Practice Nurse, such as the CRNA, knowledge of the medications administered is paramount for reduction in morbidity and mortality. As discussed earlier, one of the concerns regarding norepinephrine is the risk of tissue ischemia when peripherally administered. While the study by Medlej et al., (2017) did 
demonstrate the rate of complications to be very low, a limitation to their study was the small sample size of 55 patients. Understanding risk mitigation strategies such as utilizing a large bore IV placed in the antecubital fossa or through a central line is crucial for the APRN. It should be noted that in the five selected studies for this systematic review, none reported any complications from the peripherally administered vasopressors. Further research is warranted into the rates of complications from peripherally administrated norepinephrine and prior to any implementation of routine clinical use, a hospital policy would have to be put in place to assure proper administration.

Historically shifting clinician's workflow and habits have been met with resistance. Despite widespread evidence that phenylephrine was superior to the previously first line agent, ephedrine, it took many years for systemic change and for phenylephrine to be considered the 'gold-standard.' Even with the suggested continued research into norepinephrine's efficacy and safety within obstetrics, any changes to practice should be anticipated to be met with hesitancy. Phenylephrine is a very commonly used medication within the operating room and CRNAs are comfortable with its medication profile while norepinephrine has been typically reserved for intensive care and the cardiac anesthesia specialty. A lack of familiarity with norepinephrine could increase the challenge to any change in practice (Carvalho \& Dyer, 2015).

The use of norepinephrine over phenylephrine for the treatment of maternal hypotension could have potential benefits to patient undergoing cesarean delivery, especially patients who are already hemodynamically compromised. Further research with randomized control trials with larger cohorts needs to be conducted prior to any 
widespread change to standards of practice. Continuing education on norepinephrine's dosages, side effects and risks should be implemented prior to use. Further research should also be completed on the incidence of complications from peripherally administered norepinephrine. Through furthering the research on the use of specific vasopressors among the obstetric population, reductions to patient morbidity and mortality can hopefully be made. 


\section{References}

Butterworth, J. F., Walker, F. O., \& Lysak, S. Z. (1990). Pregnancy increases median nerve susceptibility to lidocaine. Anethesiology, 72, 962-965.

Carvalho, B., \& Dyer, R. A. (2015). Norepinephrine for spinal hypotension during cesarean delivery: Another paradigm shift? Anesthesiology, 122(4), 728-730.

Chooi, C., Cox, J. J., Lumb, R. S., Middleton, P., Chemali, M., Emmett, R. S., ... Cyna, A. M. (2017). Techniques for preventing hypotension during spinal anaesthesia for caesarean section. The Cochrane Database of Systematic Reviews, 8 , doi:10.1002/14651858.CD002251.pub3

Critical Appraisal Skills Programme. (2018). CASP randomized controlled trial checklist. Retrieved from https://casp-uk.net/wp-content/uploads/2018/01/CASPRandomised-Controlled-Trial-Checklist-2018.pdf

HCUP Fast Stats. Healthcare Cost and Utilization Project (HCUP). (2019). Retrieved from www.hcup-us.ahrq.gov/faststats/national/inpatientcommonprocedures.jsp

Kang, Y. G., Abouleish, E., \& Caritis, S. (1982). Prophylactic intravenous ephedrine infusion during spinal anesthesia for cesarean section. Anesthesia \& Analgesia, 61(10), 839-842.

Ngan Kee, W. D., Khaw, K. S., Tan, P. E., Ng, F. F. \& Karmaker, M. K. (2009). Placental transfer and fetal metabolic effects of phenylephrine and ephedrine during spinal anesthesia for cesarean delivery. The Journal of the American Society of Anesthesiologists, 111(3), 506-512.

Lee, J. E., George, R, B., \& Habib, A. S. (2017) Spinal-induced hypotension: Incidence, mechanisms, prophylaxis, and management: Summarizing 20 years of research. Best Practice \& Research. Clinical Anaesthesiology, 31(1), 57-68. doi:10.101/j.bpa.2017.01.001

Lim, G., Facco, F. L., Nathan, N., Waters, J. H., Wong, C. A., \& Eltzschig, H. K. (2018). A review of the impact of obstetric anesthesia on maternal and neonatal outcomes. Anesthesiology, 129(1), 192-215.

Medlej, K., Kazzi, A. A., Chehade A. A. H., Eldine, M. S., Chami, A., Bachir, R., ... Dagher, G. A. (2017). Complications from administration of vasopressors through peripheral venous catheters: An observational study. The Journal of Emergency Medicine, 54(1), 47-53. doi:10.1016/j.jemermed.2017.09.007 
Mercier, F.J., Augè, M., Hoffmann, C., Fischer, C., \& Le Gouez, A. (2013). Maternal hypotension during spinal anesthesia for caesarean delivery. Minerva Anestesiol, $79(1), 62-73$.

Miller, R. D., \& Pardo, M., (2011). Basics of anesthesia. St. Louis, MO: Elsevier Health Sciences.

Moher, D., Liberati, A., Tetzlaff, J., Altman, D. G., \& The PRISMA group. (2009). Preferred reporting items for systematic reviews and meta-analyses: The PRISMA statement. PLoS medicine, 6(7), 1-6. doi:10.1371/journal.pmed.0040078

Nagelhout, J.J., Elisha, S., \& Plause, K. (2013). Nurse anesthesia. St. Louis, MO: Elsevier Health Sciences.

Ngan Kee, W. D., Lee, S. W. Y., Ng, F. F., Tan, P. E., \& Khaw, K. S. (2015). Randomized double-blinded comparison of norepinephrine and phenylephrine for maintenance of blood pressure during spinal anesthesia for cesarean delivery. Anesthesiology 122(4), 736-745 doi: 10.1097/ALN.0000000000000601.

Overgaard, C. B., Džavik, V. (2008). Inotropes and vasopressors. Review of physiology and clinical use in cardiovascular disease. Circulation American Heart Association, 118, 1047-1056. doi:10.1161/ciruclationaha.107.728840

Patel, H. S. P., Shashank, M. R., \& Shivaramu, B. T. (2018). A comparative study of different intravenous bolus doses of phenylephrine used prophylactically for preventing hypotension after subarachnoid block in cesarean sections. Anesthesia: Essays and Researches, 12, 381-385.doi:10.4103/aer.AER_228_17

Richards, E., Maani, C. V. (2019). Phenylephrine. Statpearls Publishing. Retrieved from https://www.ncbi.nlm.nih.gov/books/NBK534801/

Ryu, C., Choi, G. J., Park, Y. H., \& Kang, H. (2019). Vasopressors for the management of maternal hypotension during cesarean section under spinal anesthesia: A systematic review and network meta-analysis protocol. Medicine, 98(1), e13947. doi:10.1097/MD.0000000000013947

Sewell, J. E. (1993). Cesarean section-A brief history. A brochure to accompany an exhibition on the history of cesarean section at the national library of medicine. Retrieved from https://www.nlm.nih.gov/exhibition/cesarean/index.html

Sharkey, A. M., Siddiqui, N., Downey, K., Ye, X. Y., Guevara, J., Carvalho, J. C. A.. (2018). Comparison of intermittent intravenous boluses of phenylephrine and norepinephrine to prevent and treat spinal-induced hypotension in cesarean 
deliveries: randomized controlled trial. Anesthesia \& Analgesia, 129(5), 13121318. doi:10.1213/ANE.0000000000003704

Sjöberg, T., Norgren, L., Andersson, K. E., \& Steen, S. (1989) Comparative effects of the $\alpha$-adrenoceptor agonists noradrenaline, phenylephrine and clonidine in the human saphenous vein in vivo and in vitro. Acta Physiol Scand, 136, 463-471.

Solangi, S. A., Khaskheli, M. S., \& Siddiqui, M. A. (2012). Comparison of the effects of general vs spinal anesthesia on neonatal outcome. Anaesth Pain \& Intensive Care, $16(1), 18-23$.

Stewart, A., Fernando, R., McDonald, S., Hignett, R., Jones, T., \& Columb, M. (2010). The dose-dependent effects of phenylephrine for elective cesarean delivery under spinal anesthesia. Anesthesia \& Analgesia, 111(5), 1230-1237. doi:10.1213/ANE.0b013e3181f2eae1

Thorp, J. A., Sampson, J. E., Parisi, V. M., Creasy, R. K. (1989). Routine umbilical cord blood gas determinations? American Journal of Obstetrics and Gynecology, 161(3), 600-605. doi:10.1016/0002-9378(89)90362-1

Vallejo, M. C., Attallah, A. F., Elzamzamy, O. M., Cifarelli, D.T., Phelps, A. L., Hobbs, G. R., ... Ranganathan, P. (2017). An open-label randomized controlled clinical trial for comparison of continuous phenylephrine versus norepinephrine infusion in prevention of spinal hypotension during cesarean delivery. International Journal of Obstetric Anesthesia, 29, 18-25. doi:10.1016/j.ijoa.2016.08.005

Wang, X., Mao, M., Liu, S., Xu, S., Yang, J. (2019). A comparative study of bolus norepinephrine, phenylephrine, and ephedrine, for the treatment of maternal hypotension in parturients with preeclampsia during cesarean delivery under spinal anesthesia. Medicine Science Monitor, 25, 1093-1101.

doi:10.12659/MSM.914143 


\section{Appendix A}

\section{PRISMA 2009 Checklist}

\begin{tabular}{|c|c|c|c|}
\hline Section/topic & $\#$ & Checklist item & $\begin{array}{l}\text { Reported } \\
\text { on page } \\
\text { \# }\end{array}$ \\
\hline \multicolumn{4}{|l|}{ TITLE } \\
\hline Title & 1 & Identify the report as a systematic review, meta-anslysis, or both. & \\
\hline \multicolumn{4}{|l|}{ ABSTRACT } \\
\hline Siructured summary & 2 & $\begin{array}{l}\text { Provide a structured summary including, as applicable: background; abjectives; data scurces; study eligibility } \\
\text { criteria, participants, and interventions; study appraisal and synthesis methods; results; limitations; } \\
\text { conclusions and implications of key findings; systernatic review registration number. }\end{array}$ & \\
\hline \multicolumn{4}{|l|}{ INTRODUCTION } \\
\hline Rationale & 3 & Describe the rationale for the review in the context of what is already known. & \\
\hline Objectives & 4 & $\begin{array}{l}\text { Pravide an explicit statement of questions being addressed with reference to participants, interventions, } \\
\text { comparisons, oufcomes, and study design (PICOS). }\end{array}$ & \\
\hline \multicolumn{4}{|l|}{ TMETHODS } \\
\hline Pratocol and registration & 5 & $\begin{array}{l}\text { Indicate if a review protocol exists, if and where it can be accessed (e.g., Web address), and, if available, } \\
\text { provide registration information including registration number. }\end{array}$ & \\
\hline Eligibility criteria & 6 & $\begin{array}{l}\text { Specify study characteristics (e.g., PICOS, length of follow-up) and report characteristics (e.g. years } \\
\text { considered, language, publication status) used as criteria for eligibility, giving rationale. }\end{array}$ & \\
\hline Information scurces & 7 & $\begin{array}{l}\text { Describe all information sources (e.g, databases with dates of coverage, oontact with studly authors to identify } \\
\text { additional studies) in the search and date last searched. }\end{array}$ & \\
\hline Search & 8 & $\begin{array}{l}\text { Present full electronic search strategy for at least one database, including any limits used, such that it could be } \\
\text { repeated. }\end{array}$ & \\
\hline Study selection & 9 & $\begin{array}{l}\text { State the process for selecting studies (i.e., screening, eligbility, included in systematic review, and, if } \\
\text { applicable, included in the meta-analysis). }\end{array}$ & \\
\hline Data collection process & 10 & $\begin{array}{l}\text { Describe method of data extraction from reports (e.g. piloted forms, independently, in duplicate) and any } \\
\text { processes for cbtaining and confirming data from investigators. }\end{array}$ & \\
\hline Data îems & 11 & $\begin{array}{l}\text { List and define all variables for which data were sought (e.g. PICOS, funding sources) and any assumptions } \\
\text { and simplifications made. }\end{array}$ & \\
\hline $\begin{array}{l}\text { Risk of bias in individual } \\
\text { studies }\end{array}$ & 12 & $\begin{array}{l}\text { Describe methods used for assessing risk of bias of individual studies (including specification of whether this } \\
\text { was done at the study or autcome level), and how this information is to be used in any data synthesis. }\end{array}$ & \\
\hline Summary measures & 13 & State the principal summary measures (e.g., risk ratio, difference in means). & \\
\hline Synfhesis of results & 14 & $\begin{array}{l}\text { Describe the methods of handing data and combining results of studies, if done, including measures of } \\
\text { consistency (e.g., B for each meta-analysis. }\end{array}$ & \\
\hline Sectionitopic & \# & Checklist item & $\begin{array}{l}\text { Reported } \\
\text { on page \# }\end{array}$ \\
\hline Risk of bias across studies & 15 & $\begin{array}{l}\text { Specify any assessment of risk of bias that may affect the cumulative evidence (e.g., publication bias, selective } \\
\text { reporting within studies). }\end{array}$ & \\
\hline Additional analyses & 16 & $\begin{array}{l}\text { Describe methods of additional analyses (e.g, sensitivity or subgroup analyses, meta-regression), if done, indicating } \\
\text { which were pre-specified. }\end{array}$ & \\
\hline \multicolumn{4}{|l|}{ RESULTS } \\
\hline Study selection & 17 & $\begin{array}{l}\text { Give numbers of studies screened, assessed for eligbility, and included in the review, with reasons for exclusians at } \\
\text { each stage, ideally with a flow diagram. }\end{array}$ & \\
\hline Study characteristics & 18 & $\begin{array}{l}\text { For each study, present characteristics for which data were extracted (e.g., study size, PICOS, folow-up period) and } \\
\text { provide the citations. }\end{array}$ & \\
\hline Risk of bias within studies & 19 & Present data on risk of bias of each study and, if avalable, any outoome level assessment (see item 12)- & \\
\hline Results of individual studes & 20 & $\begin{array}{l}\text { For all cutcomes considered (benefits or harms), present, for each study: (a) simple summary data for each } \\
\text { intervention group (b) effect estimates and confidence intervals, ideally with a forest plot. }\end{array}$ & \\
\hline Synthesis of results & 21 & Present results of each meta-analysis done, including confidence intervals and measures of consistency. & \\
\hline Risk of bias across studies & 22 & Present results of any assessment of risk of bias across studies (see lsem 15). & \\
\hline Addfitional analysis & 23 & Give results of addfional analyses, if done (e.g., sensitivity or subgroup analyses, meta-regression [see ltem 16]). & \\
\hline \multicolumn{4}{|l|}{ DISCUSSION } \\
\hline Summary of evidence & 24 & $\begin{array}{l}\text { Summarize the main findings including the strength of evidence for each main cutcome; consider their relavance to } \\
\text { key groups (e.g., healtheare providers, users, and policy makers). }\end{array}$ & \\
\hline Limitaticns & 25 & $\begin{array}{l}\text { Discuss limitations at study and cutcome level (e.g., risk of bias ), and at review-level (e.g., incomplese retrieval of } \\
\text { identified research, reporting bias). }\end{array}$ & \\
\hline Conclusians & 26 & Pravide a general interpretation of the results in the context of other evidence, and implications for future research. & \\
\hline \multicolumn{4}{|l|}{ FUNDING } \\
\hline Funding & 27 & $\begin{array}{l}\text { Describe sources of funding for the systematic review and other support (e.g., supply of data); role of funders for the } \\
\text { systematic review. }\end{array}$ & \\
\hline
\end{tabular}

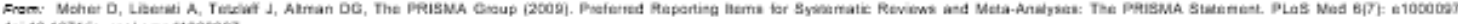
do: 10.1971 joursalpmedtoocog?

(Moher et al., 2009) 


\section{Appendix B}

Table B-1

Citation: Ngan Kee, W. D., Lee, S. W. Y., Ng, F. F., Tan, P. E., \& Khaw, K. S. (2015). Randomized double-blinded comparison of norepinephrine and phenylephrine for maintenance of blood pressure during spinal anesthesia for cesarean delivery. Anesthesiology, 122(4), 736-745. doi: 10.1097/ALN.0000000000000601.

\begin{tabular}{|c|c|c|c|c|}
\hline $\begin{array}{l}\text { Purpose: Compare } \\
\text { computer-controlled } \\
\text { infusions of } \\
\text { phenylephrine and } \\
\text { norepinephrine titrated } \\
\text { to maintain maternal } \\
\text { blood pressure in } \\
\text { parturients undergoing } \\
\text { spinal anesthesia } \\
\text { Setting/Sample: } 104 \\
\text { patients enrolled at } \\
\text { Prince of Wales } \\
\text { Hospital, Hong Kong, } \\
\text { China. Inclusion } \\
\text { criteria was ASA status } \\
\text { I-II, singleton, term } \\
\text { pregnancy, and } \\
\text { scheduled elective } \\
\text { cesarean with routine } \\
\text { spinal anesthesia. } 101 \\
\text { patients included in the } \\
\text { final study }\end{array}$ & $\begin{array}{l}\text { Anesthesia } \\
2.2 \text { mL of } \\
\text { hyperbaric } \\
\text { bupivacaine } \\
0.5 \% \text { and } \\
15 \mathrm{mcg} \\
\text { fentanyl } \\
\text { injected } \\
\text { intrathecally } \\
\text { then the } \\
\text { patient was } \\
\text { placed in } \\
\text { supine } \\
\text { position. } \\
\text { Cohydration } \\
\text { of up to 2L of } \\
\text { Hartmann's } \\
\text { solution was } \\
\text { given. }\end{array}$ & $\begin{array}{l}\text { Intervention } \\
\text { Patients were randomized into } \\
\text { either the norepinephrine group or } \\
\text { phenylephrine group and received } \\
\text { infusions of either norepinephrine } \\
5 \mathrm{mcg} / \mathrm{mL}(\mathrm{n}=49 \text { ) or } \\
\text { phenylephrine } 100 \mathrm{mcg} / \mathrm{mL}(\mathrm{n}=52) \\
\text { administered via a closed loop } \\
\text { feedback computer system based } \\
\text { off hemodynamic parameters. } \\
\text { Maternal blood pressure and heart } \\
\text { rate were measured in } 1 \text {-minute } \\
\text { intervals, CO, SVR and CI were } \\
\text { measured at } 5 \text {-minute intervals. } \\
\text { Apgar scores were assessed } 1 \\
\text { minute and } 5 \text { minutes after } \\
\text { delivery. Umbilical arterial and } \\
\text { venous blood were collected. }\end{array}$ & $\begin{array}{l}\text { Outcomes } \\
\text { HR and CO averaged higher in the } \\
\text { norepinephrine group versus the } \\
\text { phenylephrine group. Systolic BP were } \\
\text { similar between groups. SVR was lower in } \\
\text { the norepinephrine group but there was no } \\
\text { difference in SV. Incidence of bradycardia } \\
\text { (HR }<60 \text { beats/min) was higher in the } \\
\text { phenylephrine group }(55.8 \%, \mathrm{P}<0.001) \\
\text { versus norepinephrine }(18.4 \%) \text {. Three } \\
\text { patients }(6.1 \%) \text { in the norepinephrine } \\
\text { group had nausea or vomiting versus two } \\
\text { patients }(3.8 \%) \text { in the phenylephrine group } \\
\text { (p=0.67). } \\
\text { Apgar scores at } 1 \text { and } 5 \text { minutes were } \\
\text { similar between groups. UV pH and UV } \\
\text { oxygen content were higher in the } \\
\text { norepinephrine group. }\end{array}$ & $\begin{array}{l}\text { Limitations } \\
\text { CO was } \\
\text { measured via } \\
\text { suprasternal } \\
\text { doppler which } \\
\text { depends on an } \\
\text { estimate of } \\
\text { aortic valve } \\
\text { cross-sectional } \\
\text { area based of } \\
\text { patient's height } \\
\text { which } \\
\text { introduces } \\
\text { potential for } \\
\text { systematic } \\
\text { error. }\end{array}$ \\
\hline
\end{tabular}


Table B-2

Citation: Wang, X., Mao, M., Liu, S., Xu, S., Yang, J. (2019). A comparative study of bolus norepinephrine, phenylephrine, and ephedrine, for the treatment of maternal hypotension in parturients with preeclampsia during cesarean delivery under spinal anesthesia. Medicine Science Monitor, 25, 1093-1101. doi:10.12659/MSM.914143

\begin{tabular}{|c|c|c|c|c|}
\hline $\begin{array}{l}\text { Purpose: Compare } \\
\text { efficacy and safety of } \\
\text { bolus dose } \\
\text { norepinephrine, } \\
\text { phenylephrine and } \\
\text { ephedrine in parturient } \\
\text { women with } \\
\text { preeclampsia who had } \\
\text { hypotension following } \\
\text { spinal anesthesia for } \\
\text { cesarean delivery. } \\
\text { Setting/Sample: } 315 \\
\text { patients in Nanjing, } \\
\text { China. Inclusion was } \\
\text { ASA I or II, singleton, } \\
\text { non-laboring, } \\
\text { scheduled for spinal } \\
\text { anesthesia, and } \\
\text { diagnosed with pre- } \\
\text { eclampsia (BP } \\
\geq 140 / 90 \text { ) or severe } \\
\text { pre-eclampsia (BP } \\
\geq 160 / 110 \text { ). }\end{array}$ & $\begin{array}{l}\text { Anesthesia } \\
2.0-2.2 \mathrm{~mL} \text { of } \\
\text { hyperbaric } \\
\text { bupivacaine } \\
0.5 \% \text { injected } \\
\text { intrathecally } \\
\text { while the } \\
\text { patient was in } \\
\text { left lateral then } \\
\text { placed into } \\
\text { supine position } \\
\text { after } \\
\text { completion. } \\
\text { Ringer's } \\
\text { Lactate was } \\
\text { infused at a } \\
\text { maximum rate } \\
\text { of } 10 \mathrm{ml} / \mathrm{kg} \text {. }\end{array}$ & $\begin{array}{l}\text { Intervention } \\
\text { Patients were randomized into } \\
\text { either the norepinephrine group } \\
(n=56) \text {, the phenylephrine group } \\
(n=55) \text {, or the ephedrine group } \\
(n=55) \text {. } \\
\text { Maternal blood pressure and heart } \\
\text { rate were measured in 1-minute } \\
\text { intervals from intrathecal } \\
\text { injection until delivery. Maternal } \\
\text { complications such as nausea, } \\
\text { vomiting, dizziness and shivering } \\
\text { were also recorded. } \\
\text { Apgar scores were assessed } 1 \\
\text { minute and } 5 \text { minutes after } \\
\text { delivery. Umbilical arterial blood } \\
\text { gas and pH was analyzed. }\end{array}$ & $\begin{array}{l}\text { Outcomes } \\
\text { The standardized HR over time was higher } \\
\text { in the norepinephrine group then the } \\
\text { phenylephrine. Norepinephrine had a lower } \\
\text { incidence of tachycardia (HR }>120) \text { then } \\
\text { ephedrine ( } 16.1 \text { vs. } 36.4 \%, 95 \% \mathrm{CI} \text {, ) and a } \\
\text { lower incidence of bradycardia (HR }<60) \\
\text { then phenylephrine ( } 3.6 \% \text { vs. } 21.8 \%, 95 \% \\
\mathrm{CI}) \text {. Incidence of IONV, dizziness and } \\
\text { shivering were similar between } \\
\text { norepinephrine and phenylephrine. } \\
\text { Apgar and umbilical artery blood gas } \\
\text { between the norepinephrine and } \\
\text { phenylephrine groups were not significantly } \\
\text { different. }\end{array}$ & $\begin{array}{l}\text { Limitations } \\
\text { Uterine arterial } \\
\text { blood flow was } \\
\text { not measured } \\
\text { to see the } \\
\text { effects of } \\
\text { vasopressors on } \\
\text { uteroplacental } \\
\text { perfusion. All } \\
\text { factors that can } \\
\text { increase IONV } \\
\text { beyond BP } \\
\text { were not } \\
\text { assessed. }\end{array}$ \\
\hline
\end{tabular}


Table B-3

Citation: Vallejo, M. C., Attallah, A. F., Elzamzamy, O. M., Cifarelli, D.T., Phelps, A. L., Hobbs, G. R., ... Ranganathan, P. (2017). An openlabel randomized controlled clinical trial for comparison of continuous phenylephrine versus norepinephrine infusion in prevention of spinal hypotension during cesarean delivery. International Journal of Obstetric Anesthesia, 29, 18-25. doi:10.1016/j.ijoa.2016.08.005

\begin{tabular}{|c|c|c|c|c|}
\hline $\begin{array}{l}\text { Purpose: Compare } \\
\text { prophylactic, fixed-rate } \\
\text { intravenous infusion of } \\
\text { phenylephrine and } \\
\text { norepinephrine during } \\
\text { cesarean delivery under } \\
\text { spinal anesthesia. } \\
\text { Setting/Sample: } 85 \\
\text { patients from } 8 / 2014- \\
8 / 2015 \text { in West Virginia. } \\
\text { Inclusion was ASA }<3 \text {, } \\
\text { singleton gestation, }>36 \\
\text { weeks, scheduled elective } \\
\text { CD under spinal anesthesia. } \\
\text { Exclusion was hypertensive } \\
\text { disease, preeclampsia, } \\
\text { eclampsia, use of cardiac } \\
\text { medication or medication } \\
\text { for blood pressure control, } \\
\text { previous gastric bypass, } \\
\text { history of chronic opioid } \\
\text { use, BMI }>40 \text {, emergency } \\
\text { CD, history of seizures and } \\
\text { progressive neurologic } \\
\text { disease. }\end{array}$ & $\begin{array}{l}\text { Anesthesia } \\
12-15 \mathrm{mg} \\
\text { hyperbaric } \\
\text { anesthesia, } \\
\text { preservative- } \\
\text { free morphine } \\
0.2 \mathrm{mg} \text { and } \\
\text { fentanyl } \\
20 \mathrm{mcg} \text {. Ringers } \\
\text { Lactate } \\
\text { solution } 500 \mathrm{~mL} \\
\text { was } \\
\text { administered } \\
\text { over } 15 \\
\text { minutes prior } \\
\text { to spinal } \\
\text { anesthesia }\end{array}$ & $\begin{array}{l}\text { Intervention } \\
\text { Patients were randomized } \\
\text { into the phenylephrine group } \\
\text { ( } \mathrm{n}=38 \text { ), or the } \\
\text { norepinephrine group } \\
\text { ( } \mathrm{n}=43 \text { ). Four patients were } \\
\text { excluded from the } \\
\text { norepinephrine group } \\
\text { because of monitoring } \\
\text { equipment failure, or } \\
\text { emergency cesarean } \\
\text { delivery. The phenylephrine } \\
\text { group received } 100 \text { mcg/mL } \\
\text { infused at } 0.1 \text { mcg/kg/min } \\
\text { and the norepinephrine } \\
\text { group received } 0.05 \\
\text { mcg/kg/min to maintain SBP } \\
\text { within } 100-120 \% \text { of } \\
\text { baseline. Rescue boluses of } \\
100 \mathrm{mcg} \text { of phenylephrine } \\
\text { were administered if BP fell } \\
\text { below } 100 \% \text { of baseline. } \\
\text { Rescue boluses of ephedrine } \\
\text { were given for bradycardia } \\
\text { (HR }<60 \text { ). }\end{array}$ & $\begin{array}{l}\text { Outcomes } \\
\text { There were no differences between the } \\
\text { two groups in infusion duration, } \\
\text { incidence of bradycardia or incidence } \\
\text { of nausea, but the incidence of emesis } \\
\text { was greater in the phenylephrine group } \\
\text { (Group } \mathrm{P}=26.3 \% \text {, Group } \mathrm{N}=16.3 \% \text { ). } \\
\text { The proportion of patients who } \\
\text { received } \geq 1 \text { rescue phenylephrine } \\
\text { dose was similar between groups } \\
\text { (Group } \mathrm{P}=52.6 \% \text { vs. Groups } \\
\mathrm{N}=46.5 \% \text { ). The proportion of patients } \\
\text { who received } \geq 1 \text { bolus of rescue } \\
\text { ephedrine was greater in the } \\
\text { phenylephrine group (Group P: } 23.7 \% \\
\text { vs. Group N: } 2.3 \% \text { ) } \\
\text { There was no difference between } \\
\text { groups in the proportion of Apgar } \\
\text { scores }<7 \text { at } 1 \text { minute and } 5 \text { minutes or } \\
\text { in umbilical venous cord blood gases. } \\
\text { No significant differences in HR, Co, } \\
\text { CI, SV and/or SVR were found. }\end{array}$ & $\begin{array}{l}\text { Limitations } \\
\text { High rates of nausea } \\
\text { and vomiting could } \\
\text { be attributed to } \\
\text { intrathecal morphine } \\
\text { and fentanyl. The } \\
\text { study was unblinded } \\
\text { which could have } \\
\text { led to bias. Another } \\
\text { limitation is that the } \\
\text { fixed-rate infusion } \\
\text { of phenylephrine } \\
\text { was low (about } \\
8 \text { mcg/min in an } 80 \\
\text { kg woman) which is } \\
\text { lower than most } \\
\text { current regimens. } \\
\text { High incidences of } \\
\text { nausea and vomiting } \\
\text { could presumably } \\
\text { due to low rates of } \\
\text { phenylephrine. }\end{array}$ \\
\hline
\end{tabular}


Table B-4

Citation: Sharkey, A. M., Siddiqui, N., Downey, K., Ye, X. Y., Guevara, J., Carvalho, J. C. A.. (2018). Comparison of intermittent intravenous boluses of phenylephrine and norepinephrine to prevent and treat spinal-induced hypotension in cesarean deliveries: randomized controlled trial. Anesthesia \& Analgesia, 129(5), 1312-1318. doi:10.1213/ANE.0000000000003704

Purpose: To compare
norepinephrine and
phenylephrine efficacy when
used as intermittent bolus
regimens to prevent and treat
spinal-induced hypotension.
Sample/Setting: 112 women
were enrolled at Mount Sinai
Hospital in Toronto, ON, Canada
from $1 / 3 / 2017-4 / 17 / 17$.
Inclusion criteria was elective c-
section under spinal anesthesia,
ASA status $\leq I I I, \geq 18$ years of
age, singleton pregnancy, $\geq 36-$
week gestation, body weight $50-$
100kg and height $150-180 \mathrm{~cm}$.
Exclusion was
allergy/hypersensitivity to
norepinephrine or
phenylephrine, pregnancy
induced hypertension,
cardiovascular or
cerebrovascular disease, fetal
abnormalities, history of diabetes
and patient refusal.

\section{Anesthesia \\ Intervention}

$13.5 \mathrm{mg}$ of

$0.75 \%$

hyperbaric

bupivacaine

with $10 \mathrm{mcg}$ of

fentanyl and

$100 \mathrm{mcg}$

morphine.

Coloaded with

$10 \mathrm{~mL} / \mathrm{kg}$ of

Ringers Lactate

solution to a

maximum of $1 \mathrm{~L}$.
Patients were randomized

into the phenylephrine

group $(n=56)$, or the

norepinephrine group

$(\mathrm{n}=56)$. Patients were

bloused with either

$6 \mathrm{mcg} / \mathrm{mL}$ of norepinephrine

or $100 \mathrm{mcg} / \mathrm{mL}$ of

phenylephrine depending

on group allocation.

Hypotension was defined as SBP $<80 \%$ baseline.

Ephedrine 10mg was rescue medication in both groups

if SBP was below baseline and HR was $<60 \mathrm{bpm}$.
Outcomes

Incidence of bradycardia (HR $<50$

bpm) were lower in the

norepinephrine group (10.9\% versus

$37.5 \%)$. Pts in the phenylephrine

group were at a higher risk of

multiple episodes of bradycardia

versus the norepinephrine group.

There was no difference in rates of

hypotension between groups.

Patients requiring rescue boluses of ephedrine were higher in the phenylephrine group $(21.4 \%$ versus $7.2 \%$ ) There was no difference between the groups in incidence of hypertension, tachycardia, nausea, or vomiting.

No difference was found in fetal

Apgar scores at 1 and 5 minutes or in umbilical cord blood gases.
Limitations

HR was used as a surrogate marker of cardiac output and was not directly measured. 
Table B-5

Citation: Mhota, M., Garg, A., Chilkoti, G. T., Malhotra, R. K.. (2019). A randomized controlled trail of phenylephrine and noradrenaline boluses for treatment of postspinal hypotension during elective caesarean section. Association of Anaesthestists, 74, 850-855. doi:10.111/anae. 14675

\begin{tabular}{|c|c|c|c|c|}
\hline $\begin{array}{l}\text { Purpose: Compare the } \\
\text { efficacy, safety, side- } \\
\text { effect profile and } \\
\text { neonatal outcome after } \\
\text { phenylephrine and } \\
\text { norepinephrine } \\
\text { administration. } \\
\text { Sample/Setting: } 90 \\
\text { women were included } \\
\text { from December 2016- } \\
\text { January } 2018 \text { in Delhi, } \\
\text { India. Inclusion criteria } \\
\text { was an uncomplicated, } \\
\text { singleton elective c- } \\
\text { section with spinal } \\
\text { anesthesia. Exclusion } \\
\text { criteria was preexisting } \\
\text { medical conditions, } \\
\text { placenta previa, fetal } \\
\text { malformations, systolic } \\
\text { arterial pressure }<100 \\
\text { mmHg or fetal weight } \\
\text { extremes. The } \\
\text { investigators and the } \\
\text { patients were blinding to } \\
\text { medication administered. }\end{array}$ & $\begin{array}{l}\text { Anesthesia } \\
2.2 \mathrm{ml} \\
\text { hyperbaric } 0.5 \% \\
\text { bupivacaine, or } \\
2 \mathrm{~mL} \text { if patient } \\
\text { was }<150 \mathrm{~cm} \text { in } \\
\text { height. Patients } \\
\text { were coloaded } \\
\text { with } 15 \mathrm{~mL} / \mathrm{kg} \text { of } \\
\text { Ringer's Lactate } \\
\text { solution. }\end{array}$ & $\begin{array}{l}\text { Intervention } \\
\text { Patients were randomized into } \\
\text { either the phenylephrine group } \\
(\mathrm{n}=45) \text { or the norepinephrine } \\
\text { group ( } \mathrm{n}=45 \text { ). Hypotension } \\
\text { was defined as a decrease of } \\
\geq 20 \% \text { from baseline systolic } \\
\text { blood pressure or a decrease } \\
\text { below } 100 \mathrm{mmHg} \text { systolic } \\
\text { blood pressure. Bradycardia } \\
\text { was defined as a heart rate of } \\
\text { less than } 60 \text { beats per minute } \\
\text { with } 0.6 \text { mg IV of atropine } \\
\text { being the rescue medication } \\
\text { for a heart rate less than } 45 \\
\text { beats per minute. For } \\
\text { hypotensive episodes, a series } \\
\text { of } 1-\mathrm{mL} \text { bolus of either } 100 \\
\text { mcg/mL of phenylephrine or } 5 \\
\text { mcg/mL of norepinephrine } \\
\text { were administered until blood } \\
\text { pressures were corrected. }\end{array}$ & $\begin{array}{l}\text { Outcomes } \\
\text { The primary outcome measured was } \\
\text { incidence of maternal bradycardia after } \\
\text { medication administration. Incidence of } \\
\text { bradycardia were higher in the } \\
\text { phenylephrine group ( } 37.8 \% \text { ) versus the } \\
\text { norepinephrine group }(22.2 \%) \text {. No } \\
\text { differences were found in the number of } \\
\text { hypotensive periods; however, the total } \\
\text { number of boluses were higher in the } \\
\text { phenylephrine group (median dose } 200 \mathrm{mcg} \text { ) } \\
\text { versus the norepinephrine group (median } \\
\text { dose } 5 \text { mcg). The mean heart rate } 1 \text { minute } \\
\text { after study drug administration was lower in } \\
\text { the phenylephrine group ( } 76.8 \text { beats/min) } \\
\text { versus the norepinephrine group ( } 88.3 \\
\text { beats/min). There were no differences in the } \\
\text { incidence of nausea, vomiting nor dizziness. } \\
\text { Fetal umbilical blood gases were found to } \\
\text { be significantly higher in the phenylephrine } \\
\text { group verses the norepinephrine group. } \\
\text { There was no significant difference in } \\
\text { Apgar scores at } 1 \text { minute or } 5 \text { minutes. }\end{array}$ & $\begin{array}{l}\text { Limitations } \\
\text { The study } \\
\text { used a dose } \\
\text { ration of } 1: 20 \\
\text { for both } \\
\text { norepinephrin } \\
\text { e and } \\
\text { phenylephrine } \\
\text { which recent } \\
\text { studies have } \\
\text { suggested that } \\
\text { those doses } \\
\text { are not } \\
\text { equipotent. } \\
\text { Sample size } \\
\text { was also } \\
\text { smaller for } \\
\text { this study } \\
\text { which may } \\
\text { have affected } \\
\text { the true } \\
\text { difference in } \\
\text { incidence of } \\
\text { bradycardia } \\
\text { between } \\
\text { groups. }\end{array}$ \\
\hline
\end{tabular}




\section{Appendix C}

\section{Critical Appraisal Skills Program (CASP) tables}

Table C-1

Citation: Ngan Kee, W. D., Lee, S. W. Y., Ng, F. F., Tan, P. E., \& Khaw, K. S. (2015). Randomized double-blinded comparison of norepinephrine and phenylephrine for maintenance of blood pressure during spinal anesthesia for cesarean delivery. Anesthesiology, 122(4), 736745. doi: 10.1097/ALN.0000000000000601.

\begin{tabular}{|c|c|c|c|}
\hline Question & Yes & $\begin{array}{l}\text { Can't } \\
\text { Tell }\end{array}$ & No \\
\hline Did the trial address a clearly focused issue? & $\sqrt{ }$ & & \\
\hline Was the assignment of patients to treatments randomized? & $\sqrt{ }$ & & \\
\hline $\begin{array}{l}\text { Were all of the patients who entered the trial properly accounted for at its } \\
\text { conclusion? }\end{array}$ & $\sqrt{ }$ & & \\
\hline Were patients, health workers and study personnel 'blind' to treatment? & $\sqrt{ }$ & & \\
\hline Were the groups similar at the start of the trial? & $\sqrt{ }$ & & \\
\hline Aside from the experimental intervention, were the groups treated equally? & $\sqrt{ }$ & & \\
\hline $\begin{array}{l}\text { How large was the treatment effect? The primary outcomes assessed were HR } \\
\text { and CO. A varied number of blood pressure and HR measurements were recorded } \\
\text { due to the varying time for each measurement. Cardiac output was recorded a } \\
\text { minimal of four times for each patient. }\end{array}$ & $\sqrt{ }$ & & \\
\hline $\begin{array}{l}\text { How precise was the estimate of the treatment effect? The authors calculated } \\
\text { that a sample size of } 47 \text { patients per group would have greater than } 90 \% \text { power to } \\
\text { detect a } 20 \% \text { difference in cardiac output between groups. To allow for study } \\
\text { dropouts the sample size was increased by } 5 \% \text { with a goal of } 52 \text { patients per group. }\end{array}$ & $\sqrt{ }$ & & \\
\hline Can the results be applied to the local population, or in your context? & & $\sqrt{ }$ & \\
\hline Were all clinically important outcomes considered? & $\sqrt{ }$ & & \\
\hline Are the benefits worth the harms and costs? & $\sqrt{ }$ & & \\
\hline
\end{tabular}


Table C-2

Citation: Wang, X., Mao, M., Liu, S., Xu, S., Yang, J. (2019). A comparative study of bolus norepinephrine, phenylephrine, and ephedrine, for the treatment of maternal hypotension in parturients with preeclampsia during cesarean delivery under spinal anesthesia. Medicine Science Monitor, 25, 1093-1101. doi:10.12659/MSM.914143

\begin{tabular}{|c|c|c|c|}
\hline Question & Yes & $\begin{array}{l}\text { Can't } \\
\text { Tell }\end{array}$ & No \\
\hline Did the trial address a clearly focused issue? & $\sqrt{ }$ & & \\
\hline Was the assignment of patients to treatments randomized? & $\sqrt{ }$ & & \\
\hline $\begin{array}{l}\text { Were all of the patients who entered the trial properly accounted for at its } \\
\text { conclusion? }\end{array}$ & $\sqrt{ }$ & & \\
\hline Were patients, health workers and study personnel 'blind' to treatment? & $\sqrt{ }$ & & \\
\hline Were the groups similar at the start of the trial? & $\sqrt{ }$ & & \\
\hline Aside from the experimental intervention, were the groups treated equally? & $\sqrt{ }$ & & \\
\hline $\begin{array}{l}\text { How large was the treatment effect? The primary outcome was overall maternal SBP } \\
\text { and HR, secondary outcomes were incidence of tachycardia, bradycardia and } \\
\text { hypertension. }\end{array}$ & $\sqrt{ }$ & & \\
\hline $\begin{array}{l}\text { How precise was the estimate of the treatment effect? Using a pilot study as } \\
\text { reference, a minimum of } 49 \text { cases per group was needed to detect statistically } \\
\text { significant differences in maternal tachycardia. The sample size for this study was } \\
\text { increased to } 55 \text { in each group to account for drop out. }\end{array}$ & $\sqrt{ }$ & & \\
\hline Can the results be applied to the local population, or in your context? & $\sqrt{ }$ & & \\
\hline Were all clinically important outcomes considered? & $\sqrt{ }$ & & \\
\hline Are the benefits worth the harms and costs? & $\sqrt{ }$ & & \\
\hline
\end{tabular}


Table C-3

Citation: Vallejo, M. C., Attallah, A. F., Elzamzamy, O. M., Cifarelli, D.T., Phelps, A. L., Hobbs, G. R., ... Ranganathan, P. (2017). An open-label randomized controlled clinical trial for comparison of continuous phenylephrine versus norepinephrine infusion in prevention of spinal hypotension during cesarean delivery. International Journal of Obstetric Anesthesia, 29, 18-25. doi:10.1016/j.ijoa.2016.08.005

\begin{tabular}{|c|c|c|c|}
\hline Question & Yes & $\begin{array}{l}\text { Can't } \\
\text { Tell }\end{array}$ & No \\
\hline Did the trial address a clearly focused issue? & $\sqrt{ }$ & & \\
\hline Was the assignment of patients to treatments randomized? & $\sqrt{ }$ & & \\
\hline $\begin{array}{l}\text { Were all of the patients who entered the trial properly accounted for at its } \\
\text { conclusion? }\end{array}$ & $\sqrt{ }$ & & \\
\hline $\begin{array}{l}\text { Were patients, health workers and study personnel 'blind' to treatment? } \\
\text { Anesthesia providers were made aware of the study drug selected upon patient entering } \\
\text { the operating room. }\end{array}$ & & & $\sqrt{ }$ \\
\hline Were the groups similar at the start of the trial? & $\sqrt{ }$ & & \\
\hline Aside from the experimental intervention, were the groups treated equally? & $\sqrt{ }$ & & \\
\hline $\begin{array}{l}\text { How large was the treatment effect? The primary endpoint was the number and total } \\
\text { dose of rescue bolus interventions needed to maintain SBP. Incidence of N/V, } \\
\text { bradycardia, Apgar scores were also compared using the chi-square test. }\end{array}$ & $\sqrt{ }$ & & \\
\hline $\begin{array}{l}\text { How precise was the estimate of the treatment effect? A local pilot study was } \\
\text { assessed and based off power analysis } 35 \text { patients were required per group to detect a } \\
\text { reduction to } 10 \% \text { of the incidence of hypotension at the } 0.05 \text { significance level with } \\
80 \% \text { power. }\end{array}$ & $\sqrt{ }$ & & \\
\hline Can the results be applied to the local population, or in your context? & & $\sqrt{ }$ & \\
\hline Were all clinically important outcomes considered? & $\sqrt{ }$ & & \\
\hline Are the benefits worth the harms and costs? & $\sqrt{ }$ & & \\
\hline
\end{tabular}


Table C-4

Citation: Sharkey, A. M., Siddiqui, N., Downey, K., Ye, X. Y., Guevara, J., Carvalho, J. C. A.. (2018). Comparison of intermittent intravenous boluses of phenylephrine and norepinephrine to prevent and treat spinal-induced hypotension in cesarean deliveries: randomized controlled trial. Anesthesia \& Analgesia, 129(5), 1312-1318. doi:10.1213/ANE.0000000000003704

\begin{tabular}{|c|c|c|c|}
\hline Question & Yes & $\begin{array}{l}\text { Can't } \\
\text { Tell }\end{array}$ & No \\
\hline Did the trial address a clearly focused issue? & $\sqrt{ }$ & & \\
\hline Was the assignment of patients to treatments randomized? & $\sqrt{ }$ & & \\
\hline $\begin{array}{l}\text { Were all of the patients who entered the trial properly accounted for at its } \\
\text { conclusion? }\end{array}$ & $\sqrt{ }$ & & \\
\hline Were patients, health workers and study personnel 'blind' to treatment? & $\sqrt{ }$ & & \\
\hline Were the groups similar at the start of the trial? & $\sqrt{ }$ & & \\
\hline Aside from the experimental intervention, were the groups treated equally? & $\sqrt{ }$ & & \\
\hline $\begin{array}{l}\text { How large was the treatment effect? The primary outcome was the incidence of any } \\
\text { maternal bradycardia. Secondary outcomes included the incidence of hypotension, } \\
\text { hypertension, tachycardia, N/V and umbilical gases and Apgar scores. }\end{array}$ & $\sqrt{ }$ & & \\
\hline $\begin{array}{l}\text { How precise was the estimate of the treatment effect? Sample size was based of } 2 \\
\text { previous studies done by the authors group. A sample size of } 56 \text { patients per group } \\
\text { would have an } 80 \% \text { power to detect a } 70 \% \text { relative decrease in incidence of } \\
\text { bradycardia. }\end{array}$ & $\sqrt{ }$ & & \\
\hline Can the results be applied to the local population, or in your context? & $\sqrt{ }$ & & \\
\hline Were all clinically important outcomes considered? & $\sqrt{ }$ & & \\
\hline Are the benefits worth the harms and costs? & $\sqrt{ }$ & & \\
\hline
\end{tabular}


Table C-5

Citation: Mhota, M., Garg, A., Chilkoti, G. T., Malhotra, R. K.. (2019). A randomized controlled trail of phenylephrine and noradrenaline boluses for treatment of postspinal hypotension during elective caesarean section. Association of Anaesthestists, 74, 850-855. doi:10.111/anae.14675

\begin{tabular}{|c|c|c|c|}
\hline Question & Yes & $\begin{array}{l}\text { Can't } \\
\text { Tell }\end{array}$ & No \\
\hline Did the trial address a clearly focused issue? & $\sqrt{ }$ & & \\
\hline Was the assignment of patients to treatments randomized? & $\sqrt{ }$ & & \\
\hline $\begin{array}{l}\text { Were all of the patients who entered the trial properly accounted for at its } \\
\text { conclusion? }\end{array}$ & $\sqrt{ }$ & & \\
\hline Were patients, health workers and study personnel 'blind' to treatment? & $\sqrt{ }$ & & \\
\hline Were the groups similar at the start of the trial? & $\sqrt{ }$ & & \\
\hline Aside from the experimental intervention, were the groups treated equally? & $\sqrt{ }$ & & \\
\hline $\begin{array}{l}\text { How large was the treatment effect? The primary goal was to assess the incidence of } \\
\text { maternal bradycardia after study drug administration. Secondary outcomes were blood } \\
\text { pressure, vasopressor requirements, maternal complications, and neonatal outcomes. }\end{array}$ & $\sqrt{ }$ & & \\
\hline $\begin{array}{l}\text { How precise was the estimate of the treatment effect? Utilizing information from a } \\
\text { previously done study, a sample size of } 45 \text { patients was required using one-sided, } \\
\text { two=proportion z-test method with pooled variance, with a power of } 80 \% \text { at a } 5 \% \\
\text { significance level. }\end{array}$ & $\sqrt{ }$ & & \\
\hline Can the results be applied to the local population, or in your context? & $\sqrt{ }$ & & \\
\hline Were all clinically important outcomes considered? & $\sqrt{ }$ & & \\
\hline Are the benefits worth the harms and costs? & $\sqrt{ }$ & & \\
\hline
\end{tabular}


Appendix D

Data Synthesis Table

\begin{tabular}{|c|c|c|c|c|c|c|c|}
\hline $\begin{array}{l}\text { Author, } \\
\text { Year }\end{array}$ & $\begin{array}{l}\text { ASA } \\
\text { Classification \& } \\
\text { Patient } \\
\text { Characteristics }\end{array}$ & $\begin{array}{l}\text { Incidence of Maternal } \\
\text { Hypotension }\end{array}$ & $\begin{array}{l}\text { Maternal Cardiac } \\
\text { Output }\end{array}$ & $\begin{array}{l}\text { Incidence of } \\
\text { Bradycardia }\end{array}$ & $\begin{array}{l}\text { Incidence of } \\
\text { intraoperative } \\
\text { nausea/vomiting }\end{array}$ & $\begin{array}{l}\text { Neonatal } \\
\text { Apgar Scores }\end{array}$ & $\begin{array}{l}\text { Umbilical Cord } \\
\text { Gases }\end{array}$ \\
\hline $\begin{array}{l}\text { Ngan Kee et } \\
\text { al., } 2015\end{array}$ & $\begin{array}{l}\text { ASA I-II, } \geq 18 \\
\text { years old, } \\
\text { singleton, non- } \\
\text { laboring, term } \\
\text { pregnancies } \\
\text { scheduled for } \\
\text { elective cesarean } \\
\text { section. }\end{array}$ & $\begin{array}{l}\text { (Defined as SBP }<80 \% \\
\text { baseline) SBP was } \\
\text { maintained similarly } \\
\text { between groups }(\mathrm{P}=0.36)\end{array}$ & $\begin{array}{l}\text { Normalized CO at } 5 \\
\text { minutes was greater } \\
\text { in the } \mathrm{N} \text { group } \\
\text { (median } 102.7 \% \\
{[94.3-116.7 \%]} \\
\text { versus } \mathrm{P} \text { group } \\
(93.8 \%[85.0- \\
103.1 \%])(\mathrm{p}=0.004)\end{array}$ & $\begin{array}{l}\text { (Defined as } \mathrm{HR}<60 \\
\text { bpm). Lower in the } \\
\mathrm{N} \text { group }(18.4 \%) \\
\text { versus } \mathrm{P} \text { group } \\
(55.8 \%, \mathrm{p}<0.001)\end{array}$ & $\begin{array}{l}\text { No statistical } \\
\text { difference was found } \\
\text { between groups in } \\
\text { rates of } \mathrm{N} / \mathrm{V} \text { (Group } \\
\mathrm{N} n=3,6.1 \% \text {; Group } \mathrm{P} \\
\mathrm{n}=2,3.8 \% ; \mathrm{P}=0.67) \text {. }\end{array}$ & $\begin{array}{l}\text { Apgar scores for } \\
\text { both groups } \\
\text { were greater } \\
\text { than } 7 \text { at } 1 \\
\text { minute and } 5 \\
\text { minutes. } \\
\text { Average scores } \\
\text { were not } \\
\text { recorded. }\end{array}$ & $\begin{array}{l}\text { UA pH was similar } \\
\text { between groups; } \mathrm{N} \\
\text { group (7.30 [7.28- } \\
7.33]) \text { and P group } \\
(7.29 \text { [7.28-7.32]) } \\
\mathrm{P}=0.45) \text {. UA PCO2 } \\
\text { was similar between } \\
\text { groups; group } \mathrm{P}(52 \\
\text { [48-56]), Group } \mathrm{P} \\
(50[48-56]) \\
(\mathrm{P}=0.77) \\
\mathrm{UV} \text { pH was greater } \\
\text { in group } \mathrm{N}(7.35 \\
\text { [7.34-7.37]) vs } \mathrm{P} \\
\text { group }(7.34 \text { [7.32- } \\
7.36])(\mathrm{P}=0.031) \\
\mathrm{UV} \text { oxygen content } \\
\text { was higher in group } \\
\mathrm{N}(12.7[11.3-14.4]) \\
\text { vs group } \mathrm{P}(11.8 \\
[9.6-13.7]) \\
(\mathrm{P}=0.047)\end{array}$ \\
\hline $\begin{array}{l}\text { Wang et al., } \\
2019\end{array}$ & $\begin{array}{l}\text { ASA I-II, } \\
\text { singleton, non- } \\
\text { laboring, } \\
\text { scheduled for } \\
\text { spinal } \\
\text { anesthesia. } \\
\text { Parturients were } \\
\text { diagnosed with } \\
\text { pre-eclampsia } \\
\text { (BP } \geq 140 / 90\end{array}$ & $\begin{array}{l}\text { (Defined as SBP }<80 \% \\
\text { of baseline) No statistical } \\
\text { difference was found in } \\
\text { overall SBP over time } \\
\text { between groups (Group } \\
\text { N } 125.1 \pm 8.5 \text {, group P } \\
124.2 \pm 6.6 \text {, group E } \\
123.1 \pm 6.8 \text { ). } \\
\text { The number of } \\
\text { hypotensive episodes }\end{array}$ & & $\begin{array}{l}\text { (Defined as HR }<60 \\
\text { bpm) Lower in } \\
\text { group } \mathrm{N}(3.6 \%) \\
\text { versus group } \mathrm{P} \\
(21.8 \%)(\mathrm{P}=0.004)\end{array}$ & $\begin{array}{l}\text { Rates of nausea in } \\
\text { group N were }(3.5 \%) \text {, } \\
\text { group P }(5.5 \%) \text {, and } \\
\text { group E }(9.1 \%) \text {. Rates } \\
\text { of vomiting in group } \\
\mathrm{N} \text { were }(1.8 \%) \text {, group } \\
\mathrm{P}(1.8 \%) \text { and group E } \\
(11 \%) . \text { Overall } \\
\text { combined N/V rates } \\
\text { were slightly less in }\end{array}$ & $\begin{array}{l}\text { Apgar scores } \\
\text { were similar } \\
\text { among the } \\
\text { groups. No } \\
\text { Apgar score was } \\
<9 \text { at } 5 \text { minutes }\end{array}$ & $\begin{array}{l}\text { No differences were } \\
\text { found in UA blood } \\
\text { gases from group } \mathrm{N} \\
\text { and group P. UA pH } \\
\text { was higher in group } \\
\mathrm{N}(7.32 \pm 0.02) \mathrm{vs} \\
\text { group } \mathrm{E}(7.31 \pm 0.03) \\
(\mathrm{P}=0.006) . \mathrm{UA} \\
\text { lactate was lower in } \\
\text { group } \mathrm{N}(1.3 \pm 0.3)\end{array}$ \\
\hline
\end{tabular}




\begin{tabular}{|c|c|c|c|c|c|c|c|}
\hline & $\begin{array}{l}\text { with } 24 \text { hour } \\
\text { proteinuria } \geq 300 \\
\text { mg or } \geq 1+\text { with } \\
\text { dipstick) }\end{array}$ & $\begin{array}{l}\text { was statistically } \\
\text { insignificant between } \\
\text { groups. }\end{array}$ & & & $\begin{array}{l}\text { group } \mathrm{N}(5.4 \%) \\
\text { versus group } \mathrm{P}(7.3 \%) \\
\text { and group } \mathrm{E}(20 \%) \\
(\mathrm{P}=0.02) .\end{array}$ & & $\begin{array}{l}\text { vs group } \mathrm{E}(1.8 \pm 0.5) \\
(\mathrm{P}=<0.001)\end{array}$ \\
\hline $\begin{array}{l}\text { Vallejo et al., } \\
2017\end{array}$ & $\begin{array}{l}\text { ASA }<3, \\
\text { singleton, }>36 \\
\text { week scheduled } \\
\text { elective cesarean } \\
\text { delivery }\end{array}$ & $\begin{array}{l}\text { (Defined as an SBP } \\
\text { decrease }<100 \% \text { of } \\
\text { baseline) Incidence of } \\
\text { hypotension were treated } \\
\text { with recue boluses of } \\
\text { phenylephrine and/or } \\
\text { ephedrine (given for } \\
\text { hypotension with } \\
\text { bradycardia). The groups } \\
\text { were similar in who } \\
\text { received } \geq 1 \text { vasopressor } \\
\text { bolus (Group } \mathrm{P} 65.8 \% \\
{[\mathrm{n}=25] \text { vs Group } \mathrm{N}:} \\
46.5 \% \text { [n }=21], \mathrm{P}=0.12) \\
\text { The incidence one or } \\
\text { more phenylephrine } \\
\text { rescue boluses were } \\
\text { similar (Group } \mathrm{P}: 52.6 \% \\
{[\mathrm{n}=20] \text { vs. group } \mathrm{N}:} \\
46.5 \% \text { [n }=20], \mathrm{P}=0.58) . \\
\text { The incidence of } \geq 1 \\
\text { ephedrine bolus was } \\
\text { greater in group } \mathrm{P} \\
(23.7 \%,[\mathrm{n}=9]) \text { vs group } \\
\mathrm{N}(2.3 \%,[\mathrm{n}=1]) \\
(\mathrm{P}=<0.01)\end{array}$ & $\begin{array}{l}\text { No significant } \\
\text { differences were } \\
\text { found in } \mathrm{CO} \\
\text { between groups } \\
(\mathrm{P}=0.5)\end{array}$ & $\begin{array}{l}\text { (Defined as a HR } \\
<60 \mathrm{bpm} \text { ) The } \\
\text { incidence of } \\
\text { bradycardia was } \\
\text { similar between } \\
\text { groups (group } \mathrm{P} \text { : } \\
23.7 \% \text { vs group } \mathrm{N} \text { : } \\
18.6 \%, \mathrm{P}=0.58 \text { ) }\end{array}$ & $\begin{array}{l}\text { All patients received } \\
\text { prophylactic } \\
\text { ondansetron } 4 \mathrm{mg} \text { after } \\
\text { delivery of the baby. } \\
\text { Incidence of nausea } \\
\text { was similar between } \\
\text { groups (Group P } \\
63.2 \% \text { vs group N } \\
51.2 \% \text {, } \mathrm{P}=0.28) \text {. The } \\
\text { incidence of emesis } \\
\text { was greater in group } \mathrm{P} \\
(26.3 \%) \text { vs group N } \\
(16.3 \%)(\mathrm{P}<0.001)\end{array}$ & $\begin{array}{l}\text { Apgar scores }<7 \\
\text { at } 1 \text { minute were } \\
\text { similar between } \\
\text { groups (Group } \\
\mathrm{P}=6 \text { vs group } \\
\mathrm{N}=6, \mathrm{P}=0.82 \text { ). } \\
\text { Apgar scores }<7 \\
\text { at } 5 \text { minutes } \\
\text { were also } \\
\text { similar (Group } \\
\mathrm{P}=2 \text { vs group } \\
\mathrm{N}=1, \mathrm{P}=0.48 \text { ) }\end{array}$ & $\begin{array}{l}\text { UV were only } \\
\text { obtained if clinically } \\
\text { indicated. } \\
\text { UV pH were similar } \\
\text { between groups } \\
\text { (Group N } 7.30 \\
\text { [n=5] vs group N } \\
7.27 \text { [n=7], P=0.42) }\end{array}$ \\
\hline $\begin{array}{l}\text { Sharkey et } \\
\text { al., } 2018\end{array}$ & $\begin{array}{l}\text { ASA } \leq \mathrm{III}, \geq 18 \\
\text { years of age, } \\
\text { singleton } \\
\text { pregnancy }>36 \\
\text { weeks gestation, } \\
\text { patient weight } \\
50-100 \mathrm{~kg} \text {, and } \\
\text { height } 150- \\
180 \mathrm{~cm}\end{array}$ & $\begin{array}{l}\text { (Defined as an SBP } \\
<80 \% \text { of baseline value) } \\
\text { Rates of hypotension } \\
\text { were similar between the } \\
\text { two groups (group N } \\
38 \% \text { vs group P } 39 \%, \\
\mathrm{P}=0.9 \text { ). The incidence of } \\
\text { patients requiring rescue } \\
\text { boluses of ephedrine for } \\
2 \text { consecutive SBP }<80 \% \\
\text { of baseline with or } \\
\text { without a HR }<60 \mathrm{bpm} \\
\text { were lower in group N } \\
(7.2 \%) \text { vs group P } \\
(21.4 \%)\end{array}$ & & $\begin{array}{l}\text { (Defined as an HR } \\
<50 \mathrm{bpm} \text { ) Rates of } \\
\text { bradycardia were } \\
\text { lower in group N } \\
(10.9 \%) \text { versus } \\
\text { group } \mathrm{P}(37.5 \%) \\
(\mathrm{P}=<0.001)\end{array}$ & $\begin{array}{l}\text { Incidences of nausea } \\
\text { and vomiting were } \\
\text { similar between } \\
\text { groups. Group } \mathrm{P} \\
(32.1 \% \text { and } 7.1 \%) \text { vs } \\
\text { group } \mathrm{N}(27.3 \% \text { and } \\
1.8 \%)(\mathrm{P}=0.57 \text { and } \\
\mathrm{P}=0.17) \text { respectively. }\end{array}$ & $\begin{array}{l}\text { Apgar scores at } \\
1 \text { and } 5 \text { minutes } \\
\text { were }>7 \text { in all } \\
\text { cases. No } \\
\text { difference was } \\
\text { found between } \\
\text { groups. }\end{array}$ & $\begin{array}{l}\text { No difference was } \\
\text { seen in umbilical } \\
\text { cord blood gases } \\
\text { between groups }\end{array}$ \\
\hline
\end{tabular}




\begin{tabular}{|c|c|c|c|c|c|c|}
\hline $\begin{array}{l}\text { Mohta et al., } \\
2019\end{array}$ & $\begin{array}{l}\text { Uncomplicated, } \\
\text { singleton } \\
\text { pregnancies. } \\
\text { Women with } \\
\text { comorbid } \\
\text { medical } \\
\text { conditions or } \\
\text { fetal } \\
\text { compromise } \\
\text { were excluded. }\end{array}$ & $\begin{array}{l}\text { (Defined as a decrease of } \\
\geq 20 \% \text { from baseline SBP } \\
\text { or an absolute value } \\
<100 \mathrm{mmHg} \text { ). No } \\
\text { statistical difference was } \\
\text { found between the } \\
\text { groups in number of } \\
\text { hypotensive episodes, or } \\
\text { the number of boluses to } \\
\text { treat the first episode of } \\
\text { hypotension. } \\
\text { Hypotensive episodes } \\
\text { group } \mathrm{P}(\mathrm{n}=2 \text { ) vs group } \\
\mathrm{N} \text { ( } \mathrm{n}=1 \text { ), }(\mathrm{P}=0.06) \text {. The } \\
\text { total number of } \\
\text { vasopressor boluses } \\
\text { required to treat } \\
\text { hypotensive episodes } \\
\text { was higher in group } \mathrm{P} \\
\text { than group } \mathrm{N} \text { ( } \mathrm{P}=0.01 \text { ). }\end{array}$ & $\begin{array}{l}\text { (Defined as a HR of } \\
<60 \mathrm{bpm} \text { ) The } \\
\text { incidence of } \\
\text { bradycardia in group } \\
\mathrm{P} \text { was } 37.8 \% \text { verses } \\
\text { group } \mathrm{N} 22.2 \% \\
\text { ( } \mathrm{P}=0.17) \text {. Rescue } \\
\text { doses of atropine } \\
\text { were required in } \\
\text { group } \mathrm{P} 6.6 \%(\mathrm{n}=3) \\
\text { and group } \mathrm{N} 2.2 \% \\
(\mathrm{n}=1)(\mathrm{P}=0.10) . \\
\text { Mean } \mathrm{HR} \text { at } 1 \\
\text { minute after } \\
\text { vasopressor } \\
\text { administration was } \\
\text { higher in group } \mathrm{N} \\
(88.3 \mathrm{bpm}) \text { vs group } \\
\mathrm{P}(76.8 \mathrm{bpm}) \text {. }\end{array}$ & $\begin{array}{l}\text { No statistical } \\
\text { significance between } \\
\text { groups in rates of } \\
\text { nausea or vomiting. } \\
(\mathrm{P}=1.0)\end{array}$ & $\begin{array}{l}\text { Apgar scores at } \\
1 \text { and } 5 \text { minutes } \\
\text { were }>7 \text { in all } \\
\text { cases. No } \\
\text { difference was } \\
\text { found between } \\
\text { groups. }\end{array}$ & $\begin{array}{l}\mathrm{UA} / \mathrm{UV} \mathrm{pH}, \\
\text { bicarbonate, and } \\
\text { base excess were } \\
\text { higher in group } \mathrm{P} \text { vs } \\
\text { group } \mathrm{N} \text {. UA pH } \\
\text { group } \mathrm{P} \text { (mean: } \\
\text { 7.29) vs group } \mathrm{N} \\
(7.25),(\mathrm{P}=0.03) \text {. } \\
\mathrm{UA} \mathrm{pCO} 2 \text { group } \mathrm{P} \\
(52.2) \text { vs group } \mathrm{N} \\
(53.7) .(\mathrm{P}=0.52) \\
\text { Rates of neonatal } \\
\text { acidosis }(\mathrm{UA} \mathrm{pH} \\
<7.2) \text { in group } \mathrm{P} \\
(15.6 \%, \mathrm{n}=7) \mathrm{vs} \\
\text { group } \mathrm{N}(13.3 \% \text {, } \\
\mathrm{n}=6)(\mathrm{P}=0.77)\end{array}$ \\
\hline
\end{tabular}

